\title{
Are Accounting Standards Diversifiable? Evidence of the Aggregate Valuation Effects of Standards ${ }^{\Gamma}$
}

\author{
Bjorn N. Jorgensen, Jing Li, Gil Sadka*
}

April 3, 2009

\begin{abstract}
Prior research documents that individual stock returns respond to earnings differently under new accounting standards, regulations, or changes in enforcement. This paper examines whether this result extends to the aggregate stock market. We take a macro perspective and study the properties of aggregate earnings. First, we document that aggregate earnings and operating income have remained relatively stable after 1951, notwithstanding numerous changes in accounting standards. Second, we document that the relation between aggregate stock market returns and aggregate earnings also appears stable over long time periods. Third, we show that the relation between aggregate earnings, GDP and industrial production has remained stable over time as well. Finally, we show that common earnings attributes (such as asymmetric timeliness, asymmetric earnings persistence, and predictability of cash flows), while present in firm-level analyses, disappear in the aggregate.
\end{abstract}

\footnotetext{
$\Gamma$ We would like to thank Marc Giannoni, Amit Khandelwal, Nellie Kim, Efraim Sadka, Jenny Tucker (discussant at FARS) and workshop participants at 2009 Financial Accounting Research Conference, Burton Workshop, Four School Conference, Harvard University, Indiana University, University of Colorado at Boulder, University of Missouri at Columbia, University of Southern California, and Washington University in St. Louis for valuable comments and suggestions. Any errors are our own.

* Bjorn is from University of Colorado at Boulder, Jing is from Carnegie Mellon University, and Gil is from Columbia University. The authors' emails are bjorn.jorgensen@,colorado.edu, j12491@ columbia.edu, andgs2235@columbia.edu.
} 


\section{Introduction}

The accounting standards issued by the Financial Accounting Standards Board (FASB) are intended to result in financial statements that inform a diverse group of users, including equity investors. ${ }^{1}$ In a similar vein, the U.S. Securities and Exchange Commission (SEC) is mandated to protect investors. ${ }^{2}$ The information in financial statements is supposed to help financial statement users make better decisions. Yet, a basic tenant of finance theory is that investors should diversify. Therefore, it is worthwhile investigating from the perspective of a diversified investor whether the informational role of earnings is neutral to changes in accounting standards, regulations, and enforcement to date. ${ }^{3}$ Moreover, one can argue that accounting information is aimed at providing useful information to sophisticated investors that engage in "stock picking." In this case, the market portfolio provides an aggregation of all such investors and all pricing decisions.

In addition, the aggregate analysis allows investigation of the average effect on all stocks. Cross-sectional studies, commonly used to test the implications of standards, exclude by construction the average impact on all firms. Put differently, aggregate earnings measure the profitability for a "representative" firm and the market portfolio measures the return from investing in that representative firm. We note that the representative firm changes over time. For example, during the 90 s, a representative firm

\footnotetext{
1 "Financial reporting should provide information that is useful to present and potential investors and creditors and other users in making rational investment, credit, and similar decisions. The information should be comprehensible to those who have a reasonable understanding of business and economic activities and are willing to study the information with reasonable diligence." FASB (1978).

2 "The mission of the U.S. Securities and Exchange Commission is to protect investors, maintain fair, orderly, and efficient markets, and facilitate capital formation." http://www.sec.gov/about/whatwedo.shtml

${ }^{3}$ What we mean by standards includes not only SFAS, but also the enforcement by regulators, such as the SEC and auditors. As detailed below, numerous prior studies document that announcements of changes in standards can affect individual stocks and the aggregate market returns (for a recent paper, see Zhang 2007). However, these papers do not address the effect on aggregate earnings and their information role.
} 
should have a larger investment in R\&D. Since we use the aggregate earnings for each period, our analysis allows for the representative firm to change over time consistent with the changes in the economy.

Prior literature contains ample evidence supporting the notion that mandatory changes in accounting rules affect individual firms' reported earnings. This literature further documents that affected firms' stock prices react to the announcement and adoption of new accounting standards. ${ }^{4}$ As noted above, most of this literature uses cross-sectional tests that focus on the difference between firms in the cross-section and excludes the average effect on all firms. ${ }^{5}$ In this paper, we investigate simultaneously both the aggregate effect of standards to date on all firms and whether a diversified investor's portfolio is neutral against these changes in accounting standards. Specifically, we focus on the representative investor, or average investor, who by construction owns the representative firm. To test the impact of accounting standards on an average investor's use of earnings, we study the effects of accounting standards on earnings and its relation to the returns of the market portfolio. To our knowledge, our paper is the first to test the implications of accounting standards on aggregate earnings attributes as prior studies focus on firm-level and cross-sectional implications of standards.

To address our research question, we follow a recent literature that aggregates from the firm-level of analysis to the aggregate level of analysis. ${ }^{6}$ Specifically, we document for the aggregate level that the relation between earnings (measured as

\footnotetext{
${ }^{4}$ The effect of on an individual firm's reported earnings can arise either from different accruals being reported, due to say changes in accounting estimates, or from different real operating decisions.

${ }^{5}$ By analogy, macro-economic analyses of the effect of individual household incomes have considered both cross-sectional distributional effects as well as the average or aggregate growth in income over time.

${ }^{6}$ See Kothari, Lewellen, and Warner (2006), Sadka (2007), and Hirshleifer, Hou, and Teoh (2008) among others.
} 
aggregate earnings growth) and market returns has not changed significantly since the Securities Exchange Act of 1934. We document that common earnings attributes such as asymmetric timeliness have not changed over time. Specifically, we test whether the earnings-returns relation has changed with the inception of the FASB. We find no evidence that the aggregate earnings-returns relation has changed with the inception of the FASB. Consistent with Kothari, Lewellen, and Warner (2006), our findings suggest that aggregate earnings are negatively associated with contemporaneous aggregate stock returns and positively associated with lagged aggregate stock returns.

Using historical data extracted from Wilson and Jones (2002), we find that the aggregate earnings-returns relation is different in the pre-SEC period of 1870-1933 relative to the post-SEC period. We document that in the pre-SEC period aggregate earnings are positively associated with contemporaneous aggregate stock returns and positively associated with lagged aggregate stock returns. The difference in the aggregate earnings-returns relation in the pre- and post-SEC period suggests that while enforcement has affected the average investor, accounting standards have not. We caution the reader that the historical data is likely less reliable than more recent data. Also, the number of public firms included in our sample in the pre-SEC era, for which we have data, is smaller and may not represent the market portfolio.

One possible disadvantage of using the aggregate earnings-returns relation is that as earnings properties change, returns might change correspondingly. ${ }^{7}$ Therefore, although aggregate earnings have changed significantly, the aggregate earnings-returns relation could remain unchanged. To address this concern, we identify an independent

7 Jamal and Sunder (2008) document an increasing, but still relatively small, number (159) of FASB accounting standards that are complex relative to other areas of standardization, such as, the Internet Engineering Task Force. 
estimate of economic activity that does not change over time - GDP growth. This measure is important as the GDP estimates have not changed significantly since $1947 .{ }^{8}$ In contrast, during this period, many new accounting standards have been implemented, yet the relation between GDP growth and earnings growth has remained unchanged since 1947. Specifically, we find that GDP growth is positively associated with earnings growth. In addition, this relation has not changed significantly pre- and post-inception of the FASB. Since corporate earnings are a portion of GDP, we also include Industrial Production in our analysis and find similar results.

Casual inspection of aggregate earnings time series reveals that aggregate earnings were unusually low and high in 2001 and 2003, respectively. In contrast, the time series of aggregate operating income does not exhibit these two recent years as outliers. We therefore proceed to investigate whether any particular income statement line-item between operating income and earnings leads to these unusual patterns in the aggregate. We find that asset impairment of goodwill or, more generally, indefinitely lived intangible assets, cause the unusual patterns. ${ }^{9}$ These write-offs introduced what appears to be a short-lived aggregate shock to net income as a result of the implementation of SFAS 142.

We follow Ely and Waymire (1999) and investigate the effects of nonrecurring items by replicating our test using growth in operating income instead of earnings growth. First, we document that the association between aggregate earnings and market returns is more pronounced when the years 2001 through 2003 are excluded than when

\footnotetext{
${ }^{8}$ Note that 1947 is the earliest date for which the Department of Commerce produced estimates of commodity outputs. The estimation of GDP and real GDP growth does change over time. However, when the Bureau of Economic Analysis changes the estimation it restates the prior estimates of GDP such that the GDP estimates are all based on the same estimation procedure.

${ }^{9}$ This was also recognized by the press at that time, see Sender (2002).
} 
these years are included. In contrast, the association between aggregate operating earnings and market returns is consistent and independent of whether the years 2001 through 2003 are included or excluded in the analysis. In fact, the relation between growth in aggregate operating income and aggregate stock returns remains constant during the entire sample period, consistent with prices and investors being unaffected by SFAS 142. In other words, investors identified the "abnormal" decline in aggregate earnings as a short-run accounting effect.

In addition to GDP and aggregate stock returns, we also test for changes over time in some common earnings attributes, such as asymmetric timeliness. Basu (1997) documents, using cross-sectional regressions, increased asymmetric timeliness postFASB. We re-apply the tests using firm-level time-series regressions. We find evidence consistent with an increase in firm-level asymmetric timeliness. In contrast, asymmetric timeliness does not emerge for the aggregate market both pre- and post-1973. Moreover, aggregate earnings are not timely. Investors anticipate contemporaneous earnings changes during the prior year (reflected by the significant association between aggregate earnings changes and prior-year aggregate stock returns). Basu (1997) further documents asymmetric earnings persistence for positive and negative earnings changes. While we find consistent evidence in firm-level time-series tests, we fail to find consistent evidence for aggregate earnings changes. In addition, we do not find a change in the aggregate earnings persistence and/or asymmetric persistence post-1973.

Finally, we test whether earnings growth becomes a better predictor of future cash flows over time. While firm-level tests show that earnings are informative about future cash flows, aggregate earnings do not predict future cash flows. In fact, it appears that 
aggregate earnings reflect past cash flows better over time, but they do not predict future cash flows.

A number of economics papers focus on the introduction of the SEC on market returns, including Benston (1973), Simon (1989), and Stigler (1964). More recently, Beardsley and O'Brien (2003) find that the standard deviation of stock market returns have changed with the introduction of regulatory changes in Australia, UK, and US. These papers, however, generally investigate the effect of changes in accounting standard setting and enforcement without reference to or use of earnings in the analyses. In a notable exception, Ely and Waymire (1999) compare the value relevance of earnings under various accounting standard setters using the goodness-of-fit from cross-sectional firm-level regressions. They find limited evidence in support of increasing value relevance around changes in accounting setters during the 1927-1993 period. Our investigation extends their analyses by studying aggregate earnings' properties over time from 1871 to 2006. Consistent with their findings, we also find limited support of changes in aggregate earnings' properties.

One important caveat is that this paper focuses on the informational role of earnings in equity markets and that we do not address other uses of accounting information, such as the stewardship role and contracting (Watts and Zimmerman, 1986; Dye and Verrecchia, 1995; Holthausen and Watts, 2001; Sivakumar and Waymire, 2003; Watts, 2003a, 2003b; Ball, 2008; Ball, Robin and Sadka, 2008; Wittenberg-Moerman, 2008). Our findings suggest that while prior studies document that standards had a firmby-firm effect, the economy-wide effects on the representative firm and on the representative investor are negligible. Alternatively, it is possible that accounting 
standards had an impact in terms of "maintenance" such that without these standards the properties of aggregate earnings and their relation with other economic indicators would have changed (Sunder, 1996).

\subsection{Why Accounting Standards Might not Matter in the Aggregate}

There are three reasons why accounting standards might not matter in the aggregate, while affecting firm-level earnings-returns relations. The first possibility is that regulatory agencies are incapable of writing and enforcing standards that can influence the aggregate market portfolio and investors as a whole. While this argument is possible, we doubt that this is the case. There is overwhelming evidence of significant firm-level impact. In addition, the FASB is moving towards implementing fair value accounting. If this move persists and expands, there should be an aggregate effect on investors. Also, at least in one case, SFAS 142, the FASB had an easily discernable effect, albeit short-lived, on aggregate earnings.

The second possibility is that standards are generally diversifiable in the sense that some firms gain while others lose, with little or no aggregate/average effect. For example, some firms lobby in favor of a proposed standard while other firms lobby against. This pattern implies that while standards have off-setting firm-level effect, they need not have an overall impact on aggregate earnings.

The third possibility why standards might not matter in the aggregate is that standards to date dealt with "minor issues." In other words, the standards were not economically significant enough to have an aggregate effect. For example, the accounting literature has extensively studied the implications of SFAS 123. However, 
the overall value of option awards (data item OPTION_AWARDS in Compustat Executive Compensation) is approximately $0.5 \%$ of overall earnings for the firms in the sample. While it appears that SFAS 123 had an impact in terms of contracting (employee compensation), the overall stock option expenses are a fairly small amount compared to aggregate earnings. In sum, the aggregate earnings in the economy are generated mostly from the firms' "regular" operating activity and the accounting standards with regard to recognizing the profits from these activities have not changed significantly over time.

The remainder of the paper is organized as follows. Section 2 analyzes the related literature and its implications for our study. Section 3 describes the data and its sources. Section 4 reports our findings. Section 5 concludes.

\section{Related Literature}

This paper contributes to various streams of research. Prior empirical capital markets research was mainly done at the firm-level (and mostly cross-sectional). A growing empirical literature investigates whether the firm-level findings also hold in the aggregate, economy level. For example, Bernard and Thomas (1990) investigate the post-earnings announcement drift at the firm-level and portfolio-level. In contrast, Kothari, Lewellen and Warner (2006) find no evidence of post-earnings announcement drift in the aggregate. Similarly, while Sloan (1996) documents the accrual anomaly at the firm-level, Hirshleifer, Hou, and Teoh (2008) find no evidence of the accrual anomaly in the aggregate. These results suggest that market inefficiencies, which persist at the firm level, disappear at the overall economy level. Other papers that take a macroeconomic perspective on accounting issues include Sadka (2007) on the 
relationship between aggregate earnings and stock price volatility and Anilowski, Feng, and Skinner (2007) on the macro-effect of aggregate management earnings guidance.

In a similar vein, we take as given the extant literature on firm-level analyses of the economic consequences of new accounting standards. In a nice departure from the standard approach, Kohlbeck and Warfield (2008) simultaneously study multiple accounting standards on firm-level returns. In this paper, we undertake aggregate-level analyses of the consequences of new accounting standards. Specifically, we investigate whether the new accounting standards affected the portfolio held by a well-diversified investor or in other words, the aggregate portfolio held in the economy. Prior studies on the effects of accounting standards test the implications of standards for individual firms. These studies are largely cross-sectional and thus do not focus on the average effect, which is the impact on all investors.

Second, our paper relates to the literature on how mandatory disclosure rules can change the timing of arrival of information. Starting with Ross (1989), theoretical results in the finance literature predicts no effect from early resolution of uncertainty. While it is possible that early mandatory disclosure has real effects, Ross (1989) provides sufficient conditions under which the pricing kernel is unaffected by the timing of disclosure. Therefore, individual stock prices could remain the same today even with a fully anticipated change in the timing of a future disclosure. There are two scenarios under which changes in disclosure timing can have an effect on individual stock prices. First, disclosure timing can have real effects. For example, Hirshleifer (1971) shows how early disclosure can lead to a breakdown in insurance markets. Second, non-expected utility may generate prices that depend on the timing of disclosures and create a preference for 
the resolution of uncertainty. Examples of models that allow investors to have nonstandard preferences that differ from expected utility include Kreps and Porteus (1978), Duffie, Schroder, Skiadas (1996), and Grant, Kajii, and Polak (2000).

\section{Data}

We use several sources of data. In our initial tests, we rely on Compustat and CRSP data for the period 1951 through 2006. Our initial sample consists only of firms with December fiscal year-ends to avoid misspecifications due to different reporting periods. We obtain the return data from CRSP monthly file and the annual return is measured by the cumulative return from April of year $t$ until March of year $t+1$. The equal-weighted aggregate market return is calculated using all individual stocks in our sample in each year. We also obtain the net income before extraordinary items (Compustat Data \#18) and operating income after depreciation (Compustat Data \#178) from Compustat industrial annual file in each year.

Second, we perform tests for a longer, historical time-period covering the period from 1871 through 1999 using data from Wilson and Jones (2002). This gives us annual stock return data for Standard \& Poors (S\&P) index as well as earnings for all firms in that index. ${ }^{10}$ In the analysis, we exclude 1933 as earnings growth exceeds 6 , due to an increase in the number of firms included.

Finally, we use Gross Domestic Product (GDP) taken from Federal Reserve Economic Data (FRED) as an alternative "non-GAAP accounting" measure of income

\footnotetext{
${ }^{10}$ This index will include firms with non-December fiscal year ends, which may result in misspecifications due to overlapping reporting periods for firms with non-December fiscal year. Unlike our initial sample, however, we did not aggregate ourselves and do not have access to the firm-level data to only include firms with December fiscal year end.
} 
that is unaffected by changes in financial accounting rules governing private companies, whether these rules are enforced by SEC, FASB, or other standard setting bodies. In fact, the benefit of using GDP as a measure of aggregate economic activity is that its estimation has not changed since 1947. One similarity between aggregated income based on financial accounting rules and GDP is that GDP measures the value of the economy's output (goods and services) and earnings measure the profits generated from the output when it is sold. There are, however, material differences in the entity for which income is measured. For example, to avoid double counting, GDP only includes the market value of final products. In contrast, our aggregation of accounting income across companies will include revenue and expenses for "intermediate goods and services" that would have canceled out as intercompany transactions if the economy had only consisted of a single representative firm. Nonetheless, this effect is likely minor because we consider accounting income that is revenue net of expenses. Second, GDP measures the value of the economy's output including inventories, while earnings only record the profits of units that are sold and meet the accounting rules with regard to revenue recognition. Thus, current period GDP excludes market transactions based on existing goods and services, whereas accounting earnings can include gains or losses on sale of such goods and services. Third, current GDP contains gross domestic investment to improve future production, which includes the purchase of new property plant and equipment and changes in inventory as a part of revenue. Net Domestic Product deducts depreciation from GDP but is less generally available. 


\section{Summary of Analyses}

We first used Compustat data to create two accounting-based measures of aggregate income by taking the sum of all firms' earnings and operating incomes, respectively. That is, these aggregate income measures derive from the cross-sectional aggregate across all firms in the market portfolio for each calendar year. We then plotted the growth rates in these two aggregate earnings variables in Figure 1. Figure 1A shows that aggregate earnings were unusually low in 2001 and unusually high in 2003. In contrast, casual inspection of Figure 1B reveals no particular patterns in operating income for those years. We then created an aggregate income statement and found that the reason for the unusual earnings growth is due to large write-offs in the aggregate (see Figure 4) that create the unusual aggregate earnings for years 2001 through 2003 . We therefore run our subsequent analysis both with and without those years. Figure 2 shows that both our aggregate earnings measures covary with GDP. Figure 3 plots the aggregate earnings to sales ratio and aggregate operating income to sales ratio. We observe that operating income to sales ratio exhibits a relatively stable increasing pattern over the period, while the aggregate earnings to sales ratio is decreasing over the period.

Table 1 offers descriptive statistics for growth rates in our aggregate variables. Panel A presents the statistics using the data sample from Compustat from 1952 to 2006. The means for earnings and operating income are $12.3 \%$ and $11.1 \%$ respectively, and the medians for earnings and operating income are quite similar at $12.5 \%$. But the standard deviation for aggregate earnings is almost twice that of operating income, which suggests that bottom line earnings only introduce more volatility relative to operating income. The growth rate in GDP is relatively lower at about 3.3\%. The median of aggregate annual 
equal-weighted return is about $13 \%$ and the median of aggregate value-weighted return is about $15 \%$, consistent with prior literature. Panel B presents the descriptive statistics using the historical long time-series data. The average earnings growth is about $6.6 \%$, lower than that in Panel A. GDP growth is similar to recent periods.

\subsection{The Information Content of Aggregate Earnings}

We first test the time-series relation between the aggregate earnings growth and contemporaneous and lagged return. Table 2 presents the OLS results of the following regressions for different sample periods:

$$
\begin{array}{r}
R_{t-u}=\rho_{0}+\rho_{1} \cdot X_{t} / X_{t-1}+\varepsilon_{t} \\
R_{t-u}=\rho_{0}+\rho_{1} \cdot O I_{t} / O I_{t-1}+\varepsilon_{t}
\end{array}
$$

where $R_{t-u}$ is the aggregate market return in year $t-u$, for $u=0,1, X_{t} / X_{t-1}$ the growth of aggregate earnings before extraordinary items in year $t$, and $O I_{t} / O I_{t-1}$ is the growth of aggregate operating income after depreciation in year $t$. Panel A reports the results for estimating the regressions using the entire sample periods from 1951 to 2006. Panel B reports the results after excluding the years from 2001 to 2003 due to the extreme earnings change reported during this periods.

The aggregate earnings growth appears to be positively correlated with contemporaneous return and not significantly correlated with lagged return. However, after excluding 2001 to 2003 , aggregate earnings growth is negatively correlated with contemporaneous return and positively correlated with lagged return, which is consistent with findings in prior literature on aggregate earnings return relation (e.g., Kothari, Lewellen and Warner, 2006; and Sadka and Sadka, 2008). The coefficient of $X_{t} / X_{t-1}$ is - 
0.48 with $t$-statistics of -2.38 in the contemporaneous equal-weighted return regression and 0.465 with $t$-statistics of 1.982 in the lagged equal-weighted return regression. The regressions using value-weighted return also show similar results.

The aggregate operating income measure, however, is not affected by the sample period selection. The equal-weighted return regressions show that aggregate operating income growth is significantly negatively correlated with contemporaneous return and positively correlated with lagged return, including or excluding 2001 to 2003 in the sample periods. Excluding 2001 to 2003 does increase the magnitude (from - 0.442 to 0.542 ) and $t$-statistics (from -1.881 to -2.651) of the coefficient of operating income growth in the contemporaneous regression. However, the lagged regression appears to show only a marginal decrease in the coefficient magnitude and significance. The valueweighted return regressions show similar results, except that in the contemporaneous return regression the coefficient of aggregate operating income growth, although negative, is not statistically significant. Overall, operating income regression has higher $R^{2}$ than the aggregate earnings regression.

Panel $\mathrm{C}$ reports the results of aggregate earnings and return regressions using the long historical data for sample periods before and after SEC. Our analysis shows that before 1932, the earnings growth is positively related to both contemporaneous and lagged returns, while after 1932 the earnings growth is consistent with the findings using recent period data.

We proceed to test the relation between earnings (and operating income) growth and GDP growth, which we consider to be a stable measure of economic activity. Table 3 presents the results of the following regressions: 


$$
\begin{gathered}
X_{t} / X_{t-1}=\omega_{0}+\omega_{1} \cdot G D P_{t} / G D P_{t-1}+\varepsilon_{t} \\
O I_{t} / O I_{t-1}=\omega_{0}+\omega_{1} \cdot G D P_{t} / G D P_{t-1}+\varepsilon_{t}
\end{gathered}
$$

Where $X_{t} / X_{t-1}$ is the growth of aggregate earnings before extraordinary items in year $t$, and $O I_{t} / O I_{t-1}$ is the growth of aggregate operating income after depreciation in year $t$. $G D P_{t} / G D P_{t-1}$ is the growth of real GDP in year $t$.

We conduct the regressions of aggregate earnings growth and aggregate operating income growth on both GDP growth and industrial production, using different samples. The results show that both aggregate earnings growth and aggregate operating income growth are significantly correlated with contemporaneous GDP growth. ${ }^{11}$ Excluding the sample period 2001 to 2003 significantly increases the significance of correlation between aggregate earnings growth and lagged GDP growth, but does not change the magnitude of coefficient much.

In addition to GDP growth, we use industrial production as well (e.g., Fama, 1990; and Schwert, 1990). The results are reported in Table 3. The results imply that earnings growth positively relates to the growth in industrial production and that this relation is stable over time. Consistent with the results for GDP the relation between the growth in earnings and the growth in industrial production strengthens when the sample excludes the period 2001 to 2003.

Panel $\mathrm{C}$ of Table 3 presents the results using the historical data from Wilson and Jones (2002). The estimation for the period 1947-1999 shows the same results as in Panel A and B that earnings growth is positively and significantly correlated with contemporaneous GDP growth. Note that the Wilson and Jones (2002) data uses a

\footnotetext{
${ }^{11}$ Ball, Sadka and Sadka (2008) also find that aggregate earnings shocks are positively correlated with real GDP growth and industrial production.
} 
different time period (1947-1999 compared to 1952-2006 for Compustat data) and different earnings (S\&P 500 compared to the entire Compustat sample with December fiscal year end). While both the data and the time periods differ, the relation between aggregate earnings growth and GDP growth remains similar, further supporting the conclusion that accounting standard had no discernable impact on the aggregate.

The estimation for the period 1872-1932, reveals similar results. The aggregate earnings growth is significantly and positively correlated with contemporaneous GDP growth. This seems suggest that SEC had little impact on the relation between aggregate earnings and GDP measures. But note that there are fewer firms in the pre-1933 sample and different GDP calculation methods. In fact, the GDP estimates, extracted from Romer (1989), are reconstructed estimates using a variety of assumptions.

We now proceed with examining whether accounting standard changes have affected the documented earnings-return and earnings-GDP relationships in the above tables. Specifically we include a dummy variable in the regressions in table 2 and table 3 to test the pre- and post- FASB results. This dummy variable, $D_{1973}$, equals 1 for years after 1973, the year Financial Accounting Standard Board was formed, and 0 otherwise.

Table 4 presents the results of return regressions on aggregate earnings growth and operating income growth after including the interaction term between earnings growth (operating income growth) and the dummy variable. The sample in table 4 excludes the years from 2001 to 2003. Panel A presents the results using equal-weighted returns and Panel B presents the results with value-weighted returns. The coefficients of the interaction variable are not significant in both the contemporaneous and lagged equalweighted return regressions on aggregate earnings growth $\left(X_{t} / X_{t-1}\right)$. The interaction 
variable is also not statistically significant in the contemporaneous value-weighted return on aggregate earnings growth regression, but moderately significant with t-statistics of -1.694 in the lagged return. This suggests that accounting standards do not significantly change the aggregate earnings return relation. For the operating income growth measure, the coefficients of the interaction variable are also not statistically significant in general, except in the contemporaneous value-weighted return regression. The $t$-statistic of the coefficient of the interaction between the operating income growth and $D_{1973}$ is -1.813 ; in sum in the post-FASB period we do not find significant and consistent evidence on the changes in the relation between returns and both aggregate earnings and operating income growth.

Table 5 presents the results of regressions of earnings measures on GDP growth, after including the interaction between the GDP growth variable and the dummy variable. Similar to Table 4, we find that the relation between aggregate earnings (operating income) growth and GDP growth does not change significantly before and after FASB. The GDP growth remains significant in both aggregate earnings and operating income regression after including the dummy variable. The interaction between GDP growth and $D_{1973}$ is not significant in the aggregate earnings growth regression. But the interaction variable is marginally significantly negative in the operating income growth regression, with a coefficient of -2.682 and $t$-statistics of -1.815 .

We also perform the regression using industrial production and results are reported in Table 5 as well. The industrial production becomes slightly insignificant in the earnings growth regression, but remains significant in the operating income growth regression. The interactions between industrial production growth and the dummy 
variable are not significant in both earnings growth and operating income growth regressions.

\subsection{Asymmetric Timeliness and Conservatism}

Basu (1997) first proposed running the following reverse regression of earnings on returns:

$$
X_{j, t} / P_{j, t-1}=\alpha_{0, j}+\alpha_{1, j} D R_{j, t}+\beta_{1, j} R_{j, t}+\beta_{2, j} D R_{j, t} \cdot R_{j, t}+\varepsilon_{j, t}
$$

Where $D R_{j, t}=1$ if $R_{j, t}<0$ and 0 otherwise, and other variables are as defined previously. The positive coefficient of $\beta_{2, j}$ suggests that bad news is more timely recognized in earnings than good news. Basu (1997) measures conditional conservatism based on the estimated coefficients in the above equation and finds significant firm level results using the pooled and cross-sectional regressions. Other studies, such as Ball, Kothari and Robin (2000), Bushman et al. (2004), Francis et al. (2004), and Ball, Robin and Sadka (2008), also use the $R^{2}$ of this regression as a measure of timeliness of earnings. Figure 5 plots the time series of the coefficient of negative news in Basu (1997) and the dispersion of aggregate earnings in Jorgensen, Li and Sadka (2008). Both the asymmetric timeliness and earnings dispersion increase significantly after 1973, suggesting that earnings at firm level show significant changes post FASB.

We perform the Basu regression using aggregate earnings and aggregate market return. Table 6 presents the results using the Compustat sample and the long historical data sample. Overall there is no evidence of asymmetric timeliness in the aggregate data. Panel A presents the aggregate level Basu test results using the equal-weighted return and Panel B presents the aggregate level Basu test results using the value-weighted return. 
Both the equal-weighted and value-weighted return regressions show that the coefficients of both positive return and interaction with negative return are not significant in either aggregate earnings or operating income regression. When we further include the dummy variable $D_{1973}$ in the regression, the interaction between the dummy variable and negative return is not significant. Further, we also use the historical data to run the Basu regression and the results are in Panel C and D. Panel C presents results using aggregate earnings growth as dependent variable, and there is no evidence of differential asymmetric timeliness for the period after FASB was formed relative to the period from 1951 to 1973 . Panel D presents the results using aggregate earnings scaled by beginning market value and again there is no evidence of differential asymmetric timeliness for the period before SEC relative to after the SEC was formed.

For purpose of comparison, Table 7 reports the results of firm-level analyses of asymmetric timeliness pre-/post FASB. For each firm we require at least 20 observations in either pre-FASB or post-FASB period. This limits our sample size to 219 firms in preFASB period and 1079 firms in post-FASB period. We run the firm level time-series Basu regression and report the descriptive statistics of the regression coefficients in Table 7. Panel A presents the results of aggregate earnings regression and Panel B presents the results of aggregate operating income regression. The mean of coefficient $\beta_{1, j}$ in Panel A is 0.047 in pre-FASB period and 0.048 in the post-FASB period, and the two-sample $t$ test shows these two are not significantly different from each other with $t$-statistics (not reported in the table) of 0.21 . The mean of coefficient $\beta_{2, j}$ shows a significant increase from 0.034 in the pre-FASB period to 0.094 in the post-FASB period and the two-sample $t$-test also confirms that the increase is statistically significant with $t$-statistics of 4.07 (not 
reported in the table). Panel $\mathrm{B}$ shows that the mean of coefficient $\beta_{1, j}$ in the operating income regression increases from 0.089 in the pre-FASB period to 0.111 in the postFASB period and the increase is statistically significant. ${ }^{12}$ In contrast, the mean of $\beta_{2, j}$ decreases from 0.069 to 0.029 and the decrease is also statistically significant. The results confirm that the asymmetric timeliness of firm-level earnings increases significantly after 1973, but the operating income's asymmetric timeliness does not. Indeed operating income timeliness shows the opposite pattern after 1973.

Basu document that earnings persistence is also asymmetric for positive and negative news. Similar to the asymmetric persistence regression in Basu (1997), we also perform the earnings persistence regression in the aggregate level. Specifically we perform the following regressions in table 8 :

$$
\begin{gathered}
\Delta X_{t} / P_{t-1}=\phi_{0}+\phi_{1} \Delta X_{t-1} / P_{t-2}+\phi_{2} \Delta X_{t-1} / P_{t-2} * D+\varepsilon_{t} \\
\Delta O I_{t} / P_{t-1}=\phi_{0}+\phi_{1} \Delta O I_{t-1} / P_{t-2}+\phi_{2} \Delta O I_{t-1} / P_{t-2} * D+\varepsilon_{t}
\end{gathered}
$$

where $\Delta X_{t} / P_{t-1}$ and $\Delta O I_{t} / P_{t-1}$ are the changes in aggregate earnings and aggregate operating income for period $t$, scaled by the beginning market value. The dummy variable $D$ equals 1 if the corresponding $\Delta X_{t} / P_{t-1}$ or $\Delta O I_{t} / P_{t-1}$ is negative and 0 otherwise.

Panel A presents the results of earnings persistence at the aggregate level. We find no evidence of asymmetric earnings persistence at the aggregate level. The coefficient $\phi_{2}$ in both aggregate earnings and operating income regressions is negative at -0.265 and -0.663 respectively. The negative coefficient is consistent with Basu (1997) that negative earnings is more likely to reverse immediately, however, it is not statistically significant with $t$-statistics of -0.45 and -0.66 . We then include the dummy

\footnotetext{
${ }^{12}$ For more about changes over time in firm-level earnings-returns relation see Lev (1989) and Francis and Schipper (1999).
} 
variable $D_{1973}$ in the regression and interact $D_{1973}$ with other variables to test the pre and post FASB effect. The results show that the interactions term between $D_{1973}$ and other independent variables are in general insignificant. Indeed the interaction between $\Delta X_{t-1} / P_{t-2} \cdot D$ (and $\Delta O I_{t-1} / P_{t-2}{ }^{\bullet} D$ ) and $D_{1973}$ shows a positive coefficient of 2.812 (1.038), which suggests that post FASB period there is even less evidence of low persistence of negative earnings.

Similar to Table 7, we also perform the time-series regression of earnings persistence at the firm level and results are reported in Panel B of Table 8. We again require each firm has at least 20 observations to be included in the pre or post FASB period sample. This gives us 213 firms in pre FASB period and 1027 firms in the post FASB sample. In the persistence regression of total earnings, the mean of coefficient $\phi_{1}$, the persistence of positive earnings, is -0.19 in the pre-FASB period and 0.27 in the postFASB period, which suggesting that earnings become more persistent in the post-FASB period. The coefficient $\phi_{2}$ decreases from -0.339 to -0.660 and the decrease is statistically significant with t-statistics of 1.77 (not reported in the table). This shows that at firm level the negative earnings become more likely to reverse in the post-FASB period, consistent with increase in the conservatism. Overall, our results suggest that even though at firm level the earnings persistence becomes more asymmetric in the post FASB period, this does not appear at the aggregate level.

\subsection{Predictability of cash flows}

In this section, we test earnings' predictability of cash flows at the aggregate level and whether earnings have become a better predictor of cash flows in the post-FASB period. 
We use the following sets of models to test the relation between current cash flows, current earnings and future cash flows at the aggregate level:

$$
\begin{gathered}
C F O_{t+1} / C F O_{t}=\lambda_{0}+\lambda_{1} X_{t} / X_{t-1}+\lambda_{2} C F O_{t} / C F O_{t-1}+\varepsilon_{t} \\
C F O_{t+1} / C F O_{t}=\lambda_{0}+\lambda_{1} O I_{t} / O I_{t-1}+\lambda_{2} C F O_{t} / C F O_{t-1}+\varepsilon_{t} \\
C F O_{t+1} / T A_{t}=\gamma_{0}+\gamma_{1} X_{t} / T A_{t}+\gamma_{2} C F O_{t} / T A_{t}+\varepsilon_{t} \\
C F O_{t+1} / T A_{t}=\gamma_{0}+\gamma_{1} O I_{t} / T A_{t}+\gamma_{2} C F O_{t} / T A_{t}+\varepsilon_{t}
\end{gathered}
$$

The first set of models uses the growth measure of all variables. The second set of models is the same model as used in Dechow, Kothari and Watts (1998) and Kim and Kross (2005) to test the relationship between future and contemporaneous cash flows and earnings. Dechow, Kothari and Watts (1998) run a time-series regression of the model for each firm, while Kim and Kross (2005) run a cross-sectional regression of the model and examine the trend of explanatory power of earnings over time. We conduct the regression analysis of both models, with and without including the interaction term with the dummy variable $D_{1973}$. The results are presented in Table 9 .

Panel A in Table 9 presents the regression results of predicting future cash flow growth using Model (5). The results show a strong negative autocorrelation between current cash flow growth and future cash flow growth. Neither earnings growth nor operating income growth has an explanatory power in predicting future cash flow growth. The role of earnings (operating income) growth does not change in the pre and post FASB periods, as the interaction term between $X_{t} / X_{t-1}\left(O I_{t} / O I_{t-1}\right)$ and $D_{1973}$ is not statistically significant with t-statistics of $0.986(0.234)$. The results also suggest that the predictability of current cash flow growth on future cash flow growth does not change either in the post-FASB period. 
Panel B in Table 9 presents the results of predicting future cash flow using model (6). Other firm level studies (Kim and Kross, 2005; Dechow et al, 1998) usually find that both current cash flows and earnings have explanatory power in predicting future cash flows. But the analysis in Panel B of Table 9 shows slightly different results at the aggregate level: Earnings have explanatory power of future cash flow and current cash flows comparatively do not have incremental explanatory power beyond earnings; in contrast, the regression using operating income measure show that operating income does not have incremental explanatory power of future cash flows beyond current cash flows. Moreover, adding the interaction terms between the key variable and dummy variable $D_{1973}$ in the regression, we also get similar conclusion as in Panel A that earnings' predictability of future cash flows do not show significant change in the post-FASB period. Indeed the coefficient of $X_{t} / T A_{t} \cdot D_{1973}$ is negative, though not significant, which suggests that earnings have not become a better predictor of future cash flows in the postFASB period.

To further test the pre and post-FASB effect on the earnings relation to cash flows, we also compare the accrual quality (Dechow and Dichev, 2002) in the pre and post-FASB period. The accrual quality $(S t d(v))$ is measured as the standard deviation of residuals from the following regression model of total accruals on the cash flows:

$$
T C A_{t+1} / T A_{t}=\zeta_{0}+\zeta_{1} C F O_{t-1} / T A_{t}+\zeta_{2} C F O_{t} / T A_{t}+\zeta_{3} C F O_{t+1} / T A_{t}+\varepsilon_{t}
$$

Panel $\mathrm{C}$ in Table 9 reports the accrual quality results. The accrual quality shows a significant increase in the post-FASB period, with $S t d(v)$ decreases from 0.0084 to 0.0023. However further analysis of the regression coefficients indicate that the 
improvement in the accrual's mapping into cash flows comes from the past and current cash flows, not future cash flows.

Finally, we also perform the time series regression of firm-level cash flow predictability and the results are reported in Table 10. Panel A and B report the summary statistics of firm specific regressions of model (6) using earnings and operating income measures, respectively. The results show that at the firm level, earnings' ability to predict future cash flows significantly increase in the post-FASB period. The mean coefficient of earnings $\left(\gamma_{1}\right)$ of firm-specific regressions increases from 0.091 to 0.396 ; the unreported two sample t-test shows the difference is statistically significant with $t$ statistics of 4.39. The mean coefficient of operating income increases from 0.072 to 0.472 , with a $t$-statistics of 6.45 .

Panel C reports the summary statistics of firm-level accrual quality measure in the pre and post-FASB period. The result shows that the accrual quality at firm level actually decrease, as measured by the increase of the standard deviation of residual from estimation of model (7) using firm-specific time series data. However, the accruals' ability to predict future cash flows at the firm level increases, as the coefficient of future cash flows increases from 0.068 to 0.094 with an unreported $t$-statistics of 2.47 .

Overall, the firm level results suggest a significant increase of earnings' ability to predicting future cash flows, however, at the aggregate level, we do not find such significant change in the post-FASB period.

\subsection{Additional Tests}


We also perform several robustness tests using different aggregate measures. We first use aggregate earnings scaled by aggregate total assets and aggregate earnings change scaled by aggregate total assets respectively as the independent variable in the contemporaneous and lagged return regression. The results are consistent with our finding that there is no significant change in the earnings return relationship in the preand post-FASB period.

In addition, following the value relevance literature, we also run the regression of the equal-weighted and value-weighted return on the aggregate earnings and the aggregate book value, both scaled by the aggregate beginning period market value. Since the book value data starts only from 1960, our data is limited for the pre-FASB sample. However, we do not find significant change in the coefficients of both aggregate earnings and aggregate book value measures.

\section{Conclusion}

This paper studies the effects of accounting standards on earnings and their attributes from the aggregate level point of view of a well-diversified average investor, who owns the representative firm. Our findings also have implications for sophisticated investors, engaging in stock picking, because the aggregate of all such investors constitute (approximately) the aggregate market, i.e., the combined portfolio held by all sophisticated investors is approximately the market portfolio. In contrast to firm-level studies, we find that the informativeness of earnings to an average well-diversified investor is largely unaffected by changes in accounting standards. Specifically, we do not find any significant changes in aggregate earnings attributes. In other words, a 
representative investor who values the total assets in the economy, appears from this perspective to be unaffected by the new accounting standards that were passed during our sample period. As a notable exception, SFAS 142 significantly affected aggregate earnings due to increased goodwill write-offs in 2001 and 2002. Further analyses reveal that while the standard affected aggregate earnings, the average investor was largely unaffected by the accounting change. Moreover, after the initial adoption period of this standard, the relation between aggregate earnings and aggregate stock market returns appear to return to its pre-2001 relation.

We reiterate that our findings do not suggest that changes in accounting standards and practice cannot affect a diversified investor. First, it is possible that without the standards the relation between earnings and returns would have changed. Second, assuming that standards had no aggregate impact, our findings imply that the average investor was largely unaffected by accounting changes to date. Our focus is on the informational role of aggregate earnings, or lack thereof, and our analysis does not consider other uses of accounting information, such as stewardship and contracting roles. It is possible that better accounting practices have contributed to overall economic growth through more efficient contracting and investments and thus indirectly affected the diversified investor as well. Yet, our findings suggest that even if accounting practices facilitated growth, it was not because aggregate earnings provided timely information to investors. 


\section{References}

Anilowski, C., M. Feng, and D.J. Skinner. 2007. Is guidance a macro factor? The nature and information content of aggregate earnings guidance. Journal of Accounting and Economics 44: 36-63.

Ball, R. 2008. What is the actual economic role of financial reporting? Working Paper, University of Chicago.

Ball, R., and P. Brown. 1968. An empirical evaluation of accounting income numbers. Journal of Accounting Research 6 (Autumn): 159-178.

Ball, R., S.P. Kothari, and A. Robin. 2000. The effect of institutional factors on properties of accounting earnings. Journal of Accounting and Economics 29: 1-51.

Ball, E., A. Robin and G. Sadka. 2008. Is financial reporting shaped by equity markets or by debt markets? An international study of timeliness and conservatism. Review of Accounting Studies 13: 168-205.

Ball, R., G. Sadka, and R. Sadka. 2008. Aggregate earnings and asset prices. Working Paper, Columbia University.

Basu, S., 1997, The conservatism principle and the asymmetric timeliness of earnings. Journal of Accounting and Economics 24, 3-37.

Beaver, W.H., and S.G. Ryan. 2005. Conditional and unconditional conservatism: concepts and modeling. Review of Accounting Studies 10: 269-309

Benston, G. J. 1973. Required disclosure and the stock market: An evaluation of the Securities Exchange Act of 1934. American Economic Review 63: 132-155.

Bernard, V., and J. Thomas. 1990. Evidence that stock prices do not fully reflect the implications of current earnings for future earnings. Journal of Accounting and Economics 13: 305-340.

Bushman, R., Q. Chen, E. Engel, and A. Smith. 2004. Financial accounting information, organizational complexity and corporate governance systems. Journal of Accounting and Economics 37: 139-201.

Beardsley, C., and J. R. O'Brien. 2004. The effectiveness of mandatory disclosure under Britain's Financial Service Authority: An economic analysis. Working paper, CarnegieMellon University.

Dechow, P.M., and I. Dichev, 2002, The quality of accruals and earnings: The role of accrual estimation errors. The Accounting Review 77 (Supplement): 35-59. 
Dechow, P.M., S.P. Kothari, and R.L. Watts, 1998, The relation between earnings and cash flows. Journal of Accounting and Economics 25: 133-168.

Duffie, D., M. Schroder, and C. Skiadas. 1996. Recursive valuation of defaultable securities and the timing of the resolution of uncertainty. Annals of Applied Probability 6: 1075-1090.

Dye, R., and R. Verrecchia. 1995. Discretion vs. uniformity: Choices among GAAP. The Accounting Review 70: 389-416.

Ely, K., and G. Waymire. 1999. Accounting standard-setting organizations and earnings relevance: Longitudinal evidence from NYSE common stocks, 1927-93. Journal of Accounting Research 37: 293-317.

Fama, Eugene F., 1990, Stock returns, expected returns, and real activity, Journal of Finance 45, 1089-1108.

Financial Accounting Standards Board. 1978. Concepts Statement No. 1. Objectives of Financial Reporting by Business Enterprises (Issue Date November 1978). http://www.fasb.org/pdf/con1.pdf

Francis, J., R. LaFond, P.M. Olsson, and K. Schipper. 2004. The costs of equity and earnings attributes. The Accounting Review 79: 967-1010.

Francis, J., and K. Schipper. 1999. Have financial statements lost their relevance? Journal of Accounting Research 37: 319-352.

Grant, S., A. Kajii, and B. Polak. 2000. Temporal resolution of uncertainty and recursive non-expected utility models. Econometrica $68: 425-434$

Hirshleifer, J. 1971. The private and social value of information and the reward to inventive activity. The American Economics Review 61: 561-574

Hirshleifer, D., K. Hou, and S.H. Teoh. 2008. Accruals and aggregate stock market returns. Journal of Financial Economics (forthcoming).

Holthausen, R.W., and R.L. Watts. 2001. The relevance of the value-relevance literature for financial accounting standard setting. Journal of Accounting and Economics 31: 3-75.

Jamal, K., and S. Sunder. 2008. Monopoly and Competition: Standard Setting in the Public and Private Sector. Working paper, Yale School of Management. 
Jorgensen, B., J. Li, and G. Sadka, 2008, Earnings dispersion and aggregate stock returns. Working paper, Columbia University.

Kim, M. and W. Kross, 2005, The ability of earnings to predict future operating cash flows has been increasing---not decreasing. Journal of Accounting Research 43: 753-780.

Kohlbeck, M.J., and T. Warfield. 2008. The effects of accounting standard setting on accounting quality. Working Paper, University of Wisconsin at Madison.

Kothari, S.P., J.W. Lewellen and J.B. Warner. 2006. Stock returns, aggregate earnings surprises and behavioral finance. Journal of Financial Economics 79: 537-568.

Kreps, D.M., and E.L. Porteus. 1978. Temporal resolution of uncertainty and dynamic choice theory. Econometrica 46: 185-200.

Lev, B. 1989. On the usefulness of earnings and earnings research: Lessons and directions from two decades of empirical research. Journal of Accounting Research 27: 153-192.

Romer, C.D. 1989. The prewar business cycle reconsidered: New estimates of gross national product, 1869-1908. Journal of Political Economy 97: 1-37.

Ross, S.A. 1989. Information and volatility: The no-arbitrage martingale approach to timing and resolution irrelevancy. The Journal of Finance 44: 1-17.

Sadka, G. 2007. Understanding stock-price volatility: The role of earnings. Journal of Accounting Research 48: 199-228.

Sadka, G., and R. Sadka. 2008. Predictability and the earnings-returns relation. Journal of Financial Economics (forthcoming).

Schwert, G. William, 1990, Stock returns and real activity: A century of evidence, Journal of Finance 45, 1237-1257.

Sender, H. 2002. Flood of Firms to Take Goodwill Write-Downs. The Wall Street Journal, April 24, page C5.

Simon, C. J. 1989. The effect of the 1933 Securities Act on investor information and the performance of new issues. American Economic Review 79: 295-318.

Sivakumar, K., and G. Waymire. 2003. Enforceable accounting rules and income measurement by early $20^{\text {th }}$ century railroads. Journal of Accounting Research 41: 397432. 
Sloan, R. 1996. Do stock price fully reflect information in accruals and cash flows about future earnings? The Accounting Review 71: 289-315.

Stigler, G. 1964. Public regulation of the securities markets. Journal of Business 37: 117142.

Sunder, S. 1996. Theory of Accounting and Control. South-Western College Publications.

Watts, R. L. 2003a. Conservatism in accounting part I: Explanations and implications. Accounting Horizons 17: 207-221.

Watts, R.L. 2003b. Conservatism in accounting part II: Evidence and research opportunities. Accounting Horizons 17: 287-301.

Watts, R.L., and J.L. Zimmerman. 1986. Positive accounting theory. Englewood Cliffs, N.J.: Prentice-Hall.

Wittenberg Moerman, R. 2008. The role of information asymmetry and financial reporting quality in debt contracting: Evidence from the secondary loan market. Journal of Accounting and Economics (forthcoming).

Wilson, J.W., and C.P. Jones. 2002. An analysis of the S\&P 500 index and Cowles's extensions: Price indexes and stock returns, 1870-1999. The Journal of Business 75: 505533.

Zhang, Ivy Xiying. 2007. Economic consequences of the Sarbanes-Oxley Act of 2002. Journal of Accounting and Economics 44: 74-115. 
Figure 1a Aggregate Earnings Growth $\left(X_{t} / X_{t-1}\right), 1951-2006$

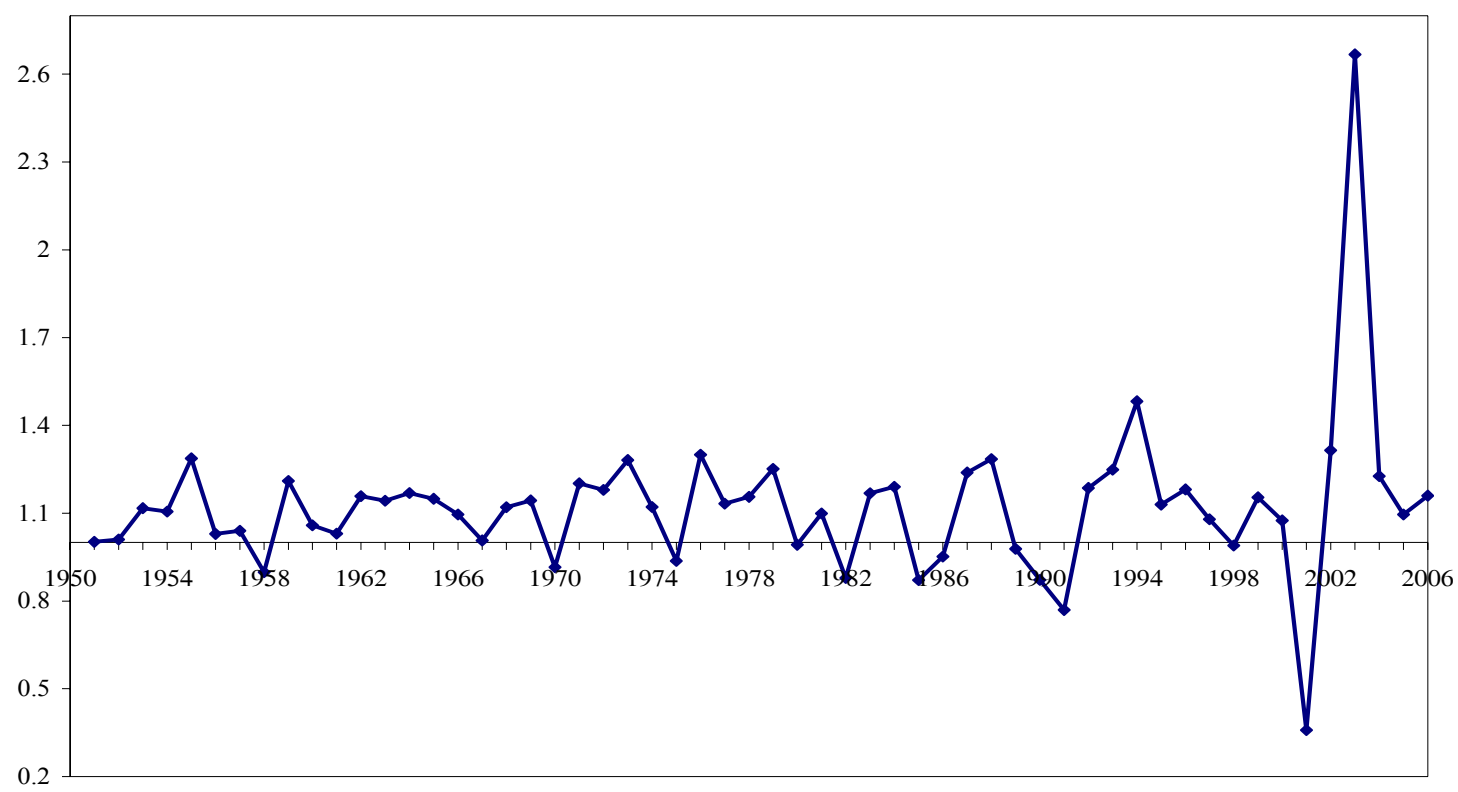

Figure 1b Aggregate Operating Income Growth $\left(O I_{t} / O I_{t-1}\right), 1951-2006$

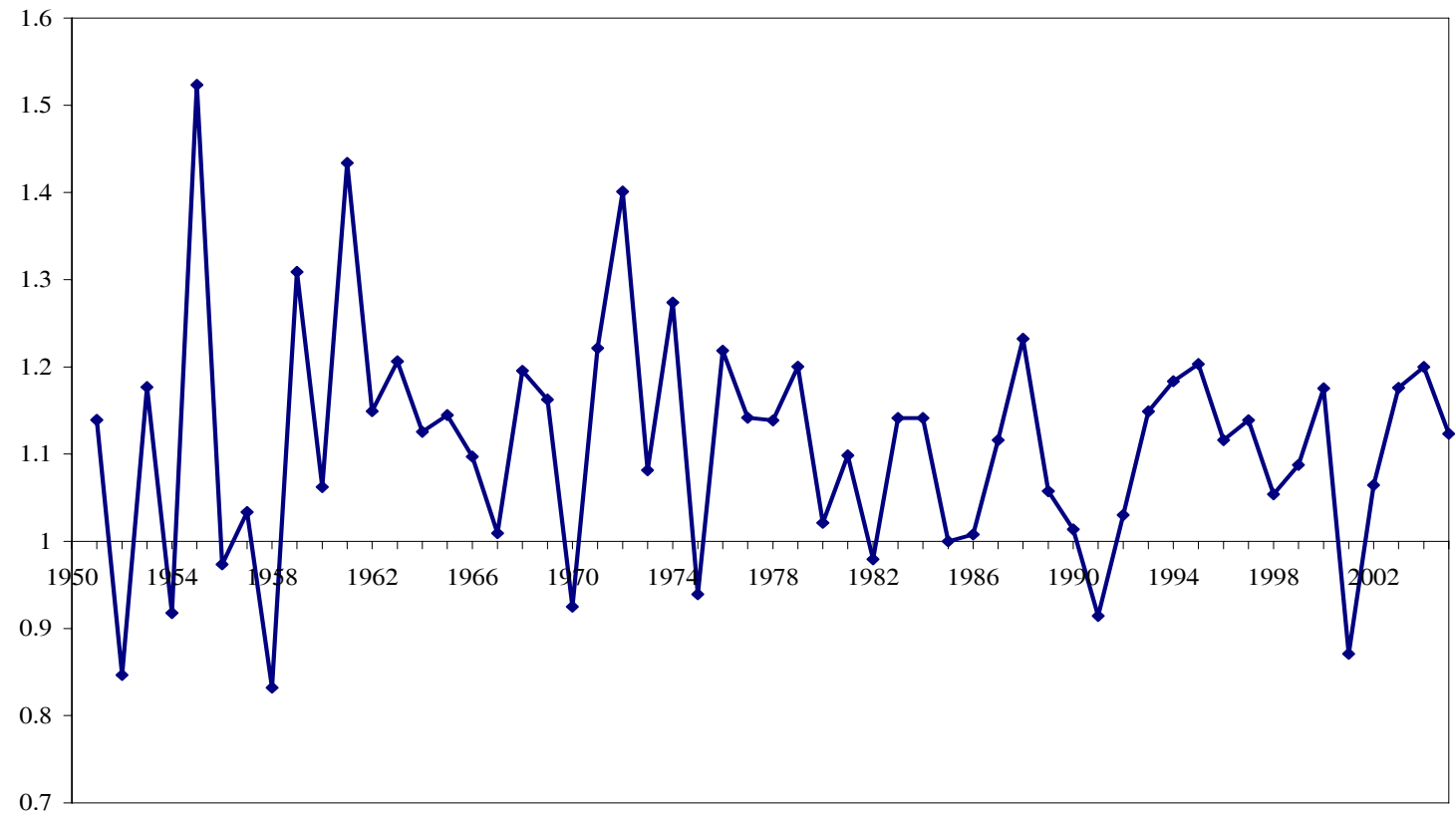

Figure 1 plots the time series of aggregate earnings growth $\left(X_{t} / X_{t-1}\right)$ and aggregate operating income growth $\left(O I_{t} / O I_{t-1}\right)$ for all firms in our sample from 1951 to 2006. $X_{t}$ is the aggregate total net income before extraordinary items (Compustat \#18) in year t. $O I_{t}$ is the aggregate operating income after depreciation (Compustat \#178) in year $\mathrm{t}$. 
Figure 2a Aggregated Earnings Growth vs. Real GDP Growth, 1951-2006

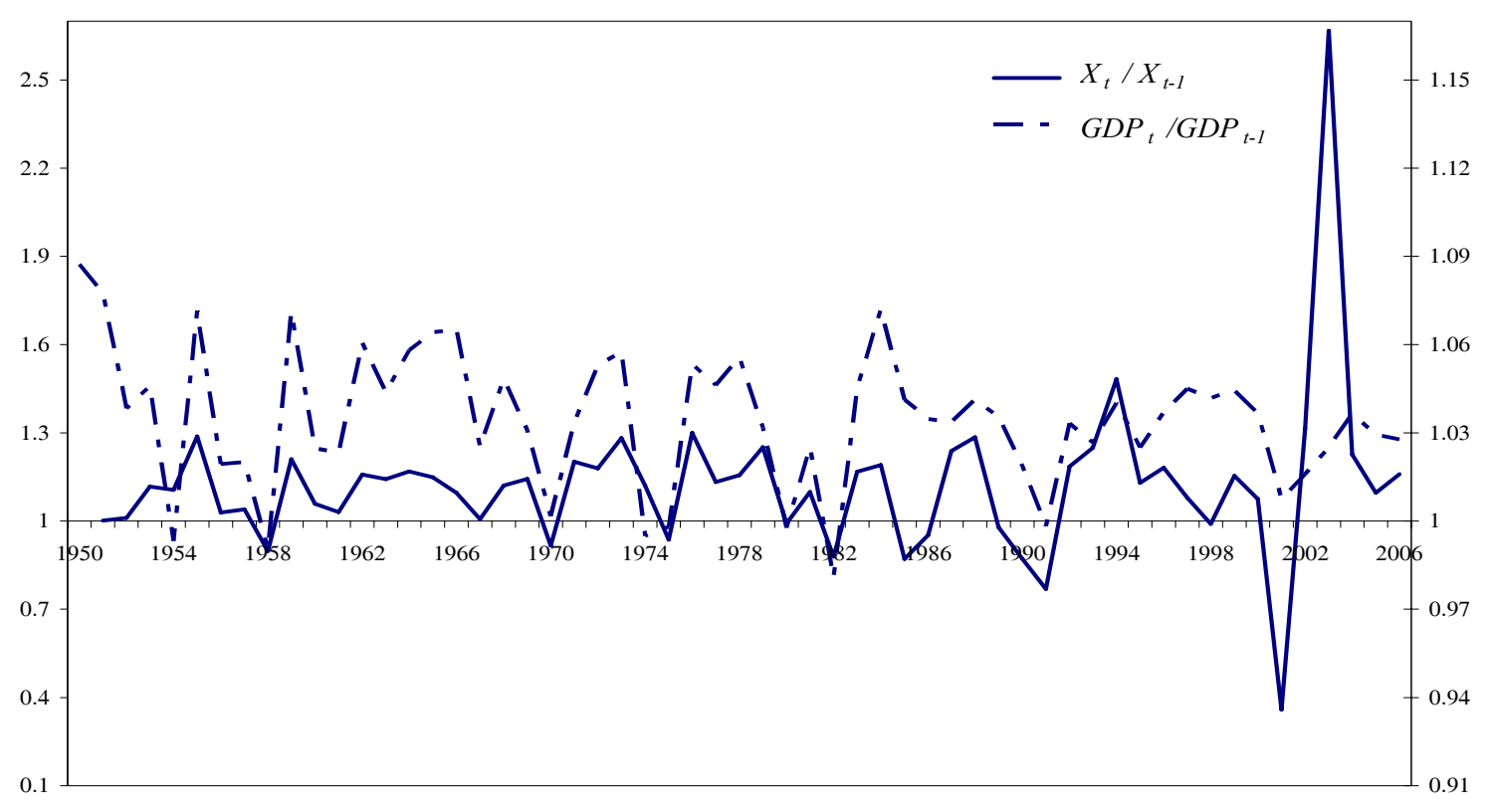

Figure 2b Aggregated Operating Income Growth vs. Real GDP Growth, 1951-2006

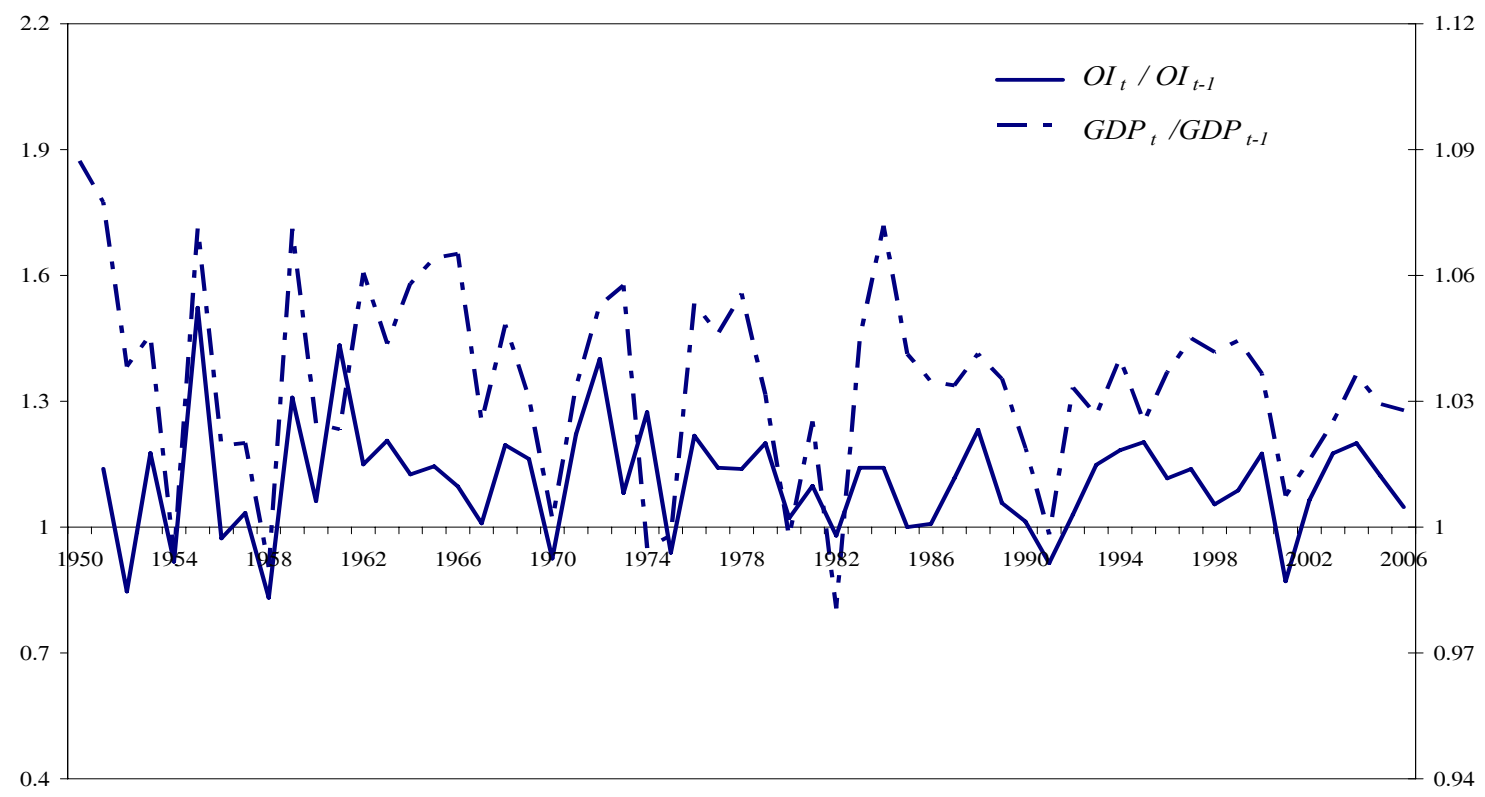

Figure 2 plots the time series of aggregate earnings growth $\left(X_{t} / X_{t-1}\right)$ and aggregate operating income growth $\left(O I_{t} / O I_{t-1}\right)$ compared with real GDP growth $\left(G D P_{t} / G D P_{t-1}\right)$ from 1951 to 2006. $X_{t}$ is the aggregate total net income before extraordinary items (Compustat \#18) in year t. $\mathrm{OI}_{t}$ is the aggregate operating income after depreciation (Compustat \#178) in year t. $G D P_{t}$ is the real Gross National Product in year t. 
Figure 3a Aggregated Earnings to Sales Ratio $\left(X_{t} /\right.$ Sales $\left._{t-1}\right), 1950-2006$

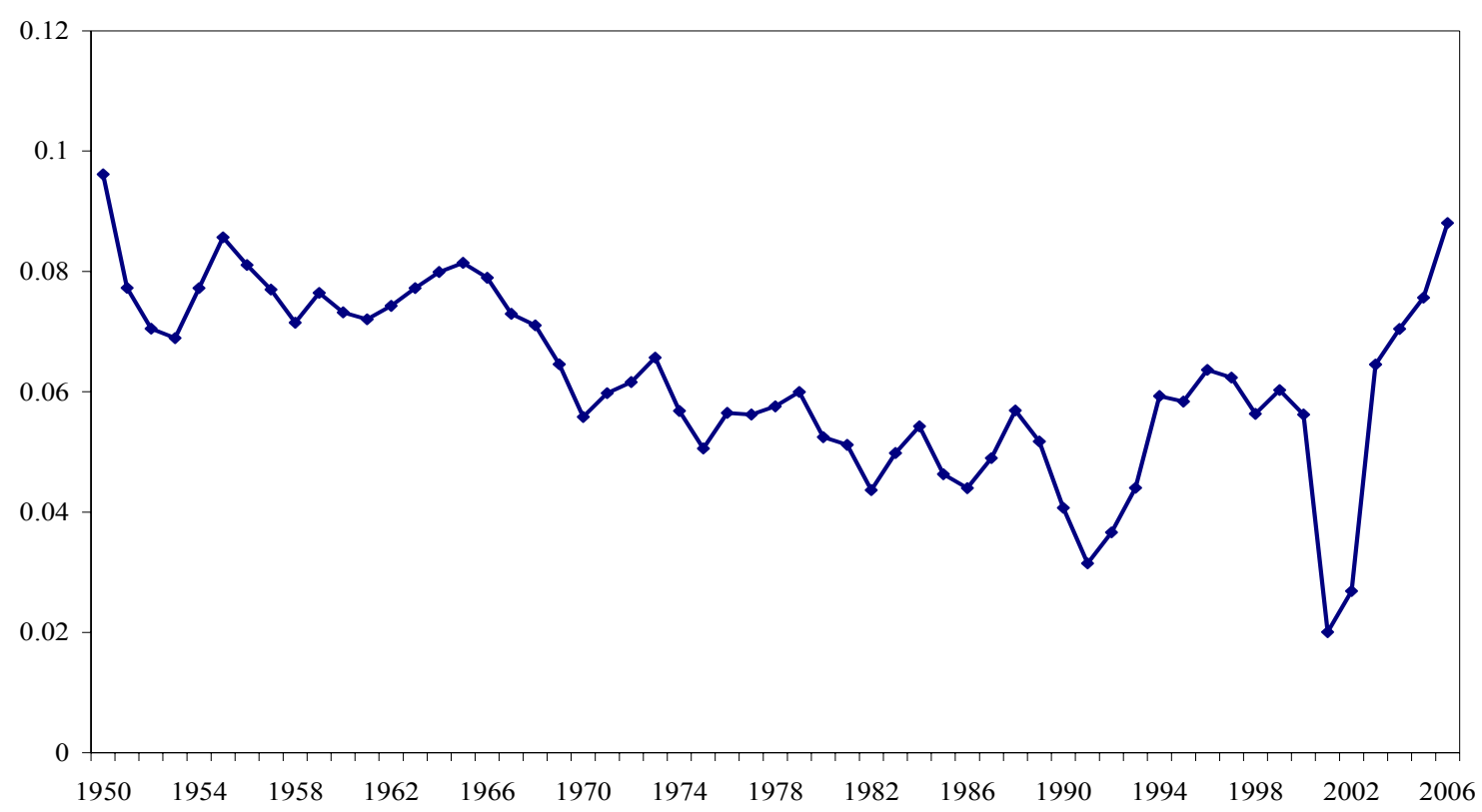

Figure 3b Aggregated Operating Income to Sales Ratio (OI $t_{t}$ Sales $\left._{t-1}\right), 1950-2006$

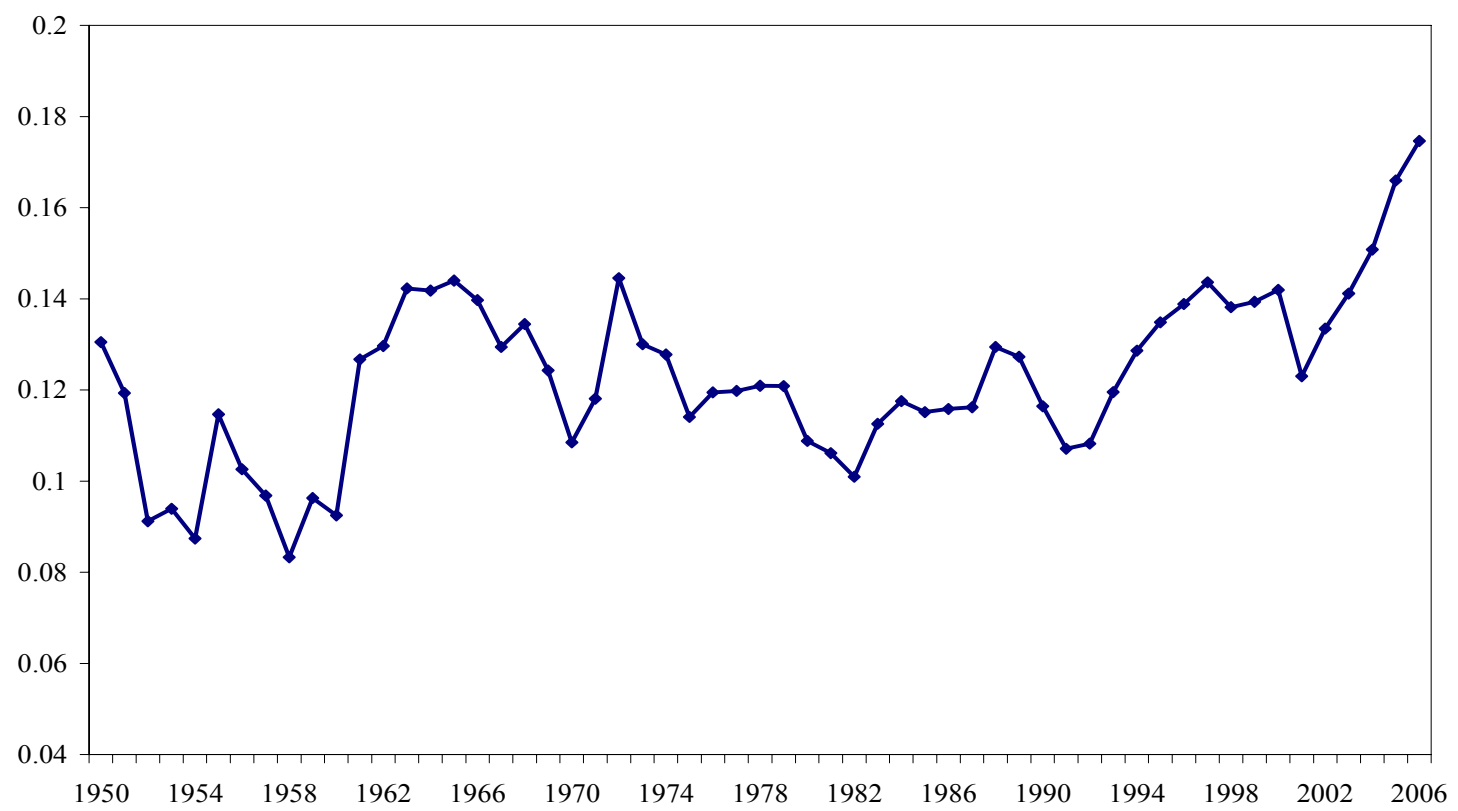


Figure 3c Aggregated Operating Income to Earnings Ratio, 1950-2006

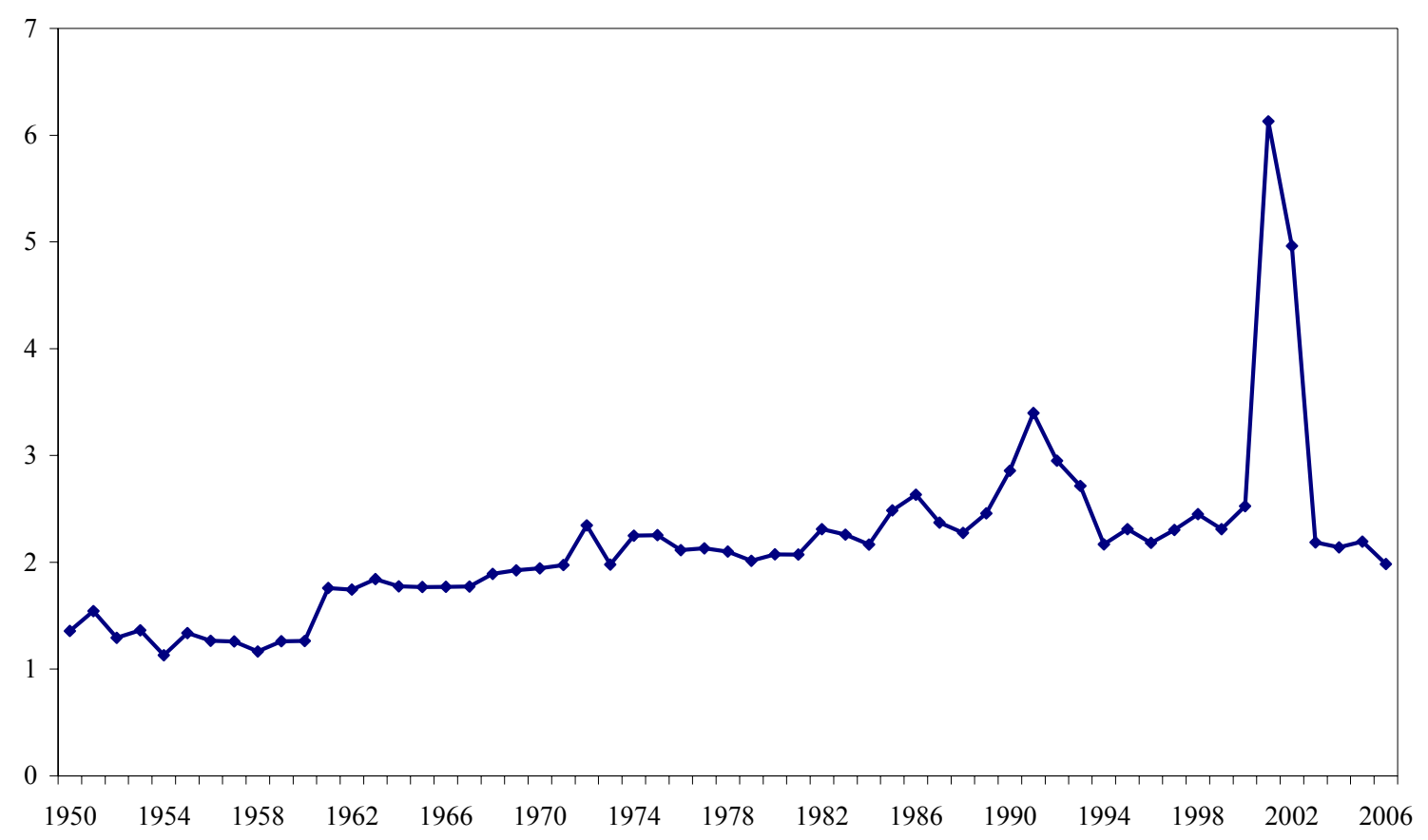

Figure 3 plots the time series of aggregate earnings to sales ratio $\left(X_{t} /\right.$ Sales $\left._{t}\right)$, aggregate operating income to sales ratio $\left(\mathrm{OI}_{t} /\right.$ Sales $\left._{t}\right)$, and aggregate operating income to earnings ratio $\left(O I_{t} / X_{t}\right)$ for all firms in our sample from 1951 to 2006. $X_{t}$ is the aggregate total net income before extraordinary items (Compustat \#18) in year t. $O I_{t}$ is the aggregate operating income after depreciation (Compustat \#178) in year t. Sales ${ }_{t}$ is the aggregate sales revenue (Compustat \#12) in year $\mathrm{t}$. 
Figure 4 Aggregated Write Down to Operating Income Ratio $\left(W D_{t} / O I_{t}\right), 1996-2006$

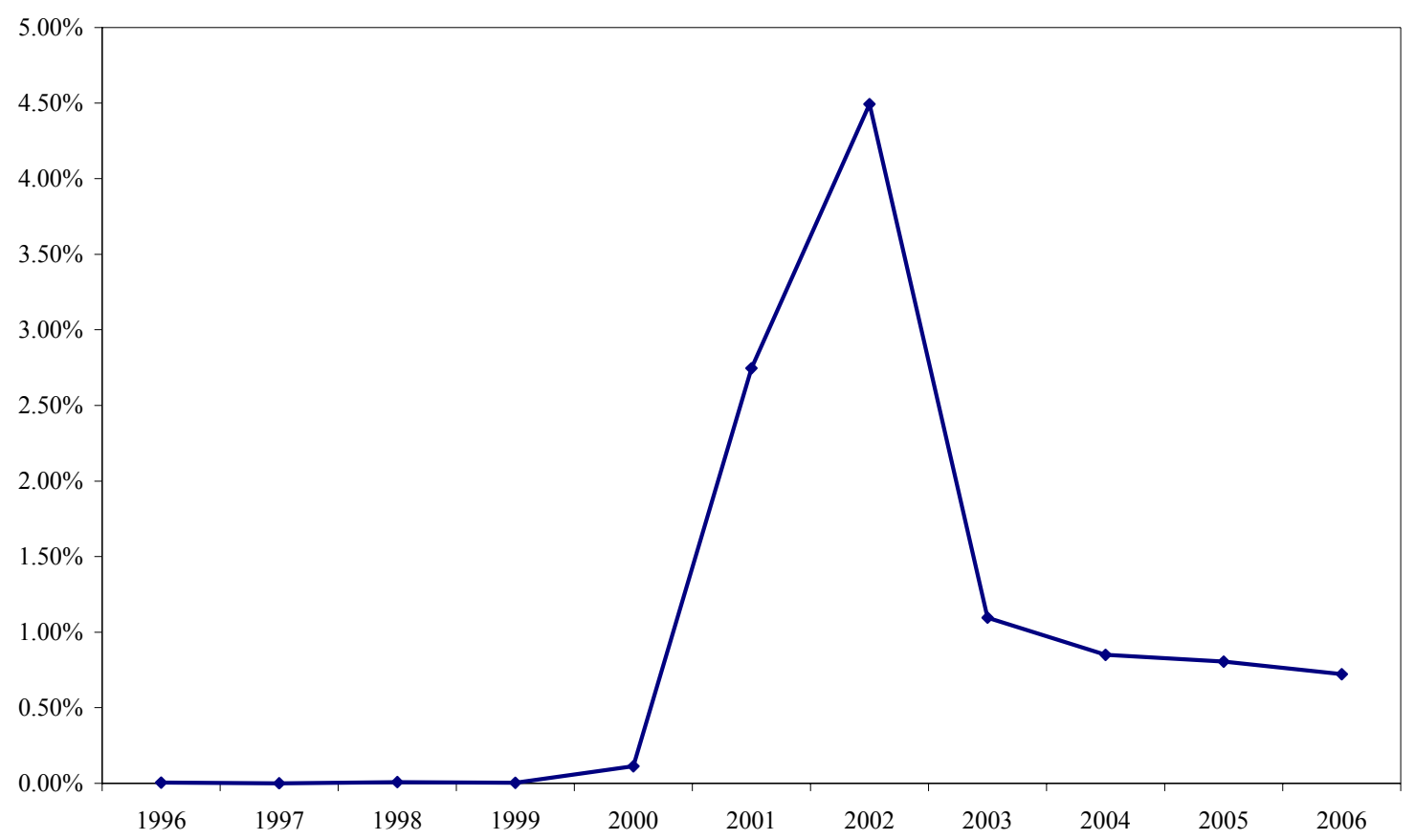

Figure 4 plots the aggregate assets write down to operating income ratio $\left(W D_{t} / O I_{t}\right)$ during the period when the data of write down is available, 1996-2006. $W D_{t}$ is the aggregate write down (Compustat \#381) in year t. $\mathrm{OI}_{t}$ is the aggregate operating income after depreciation (Compustat \#178) in year t. 
Figure 5 Raw Dispersion of Earnings and

Coefficient of Negative Returns in Basu (1997)

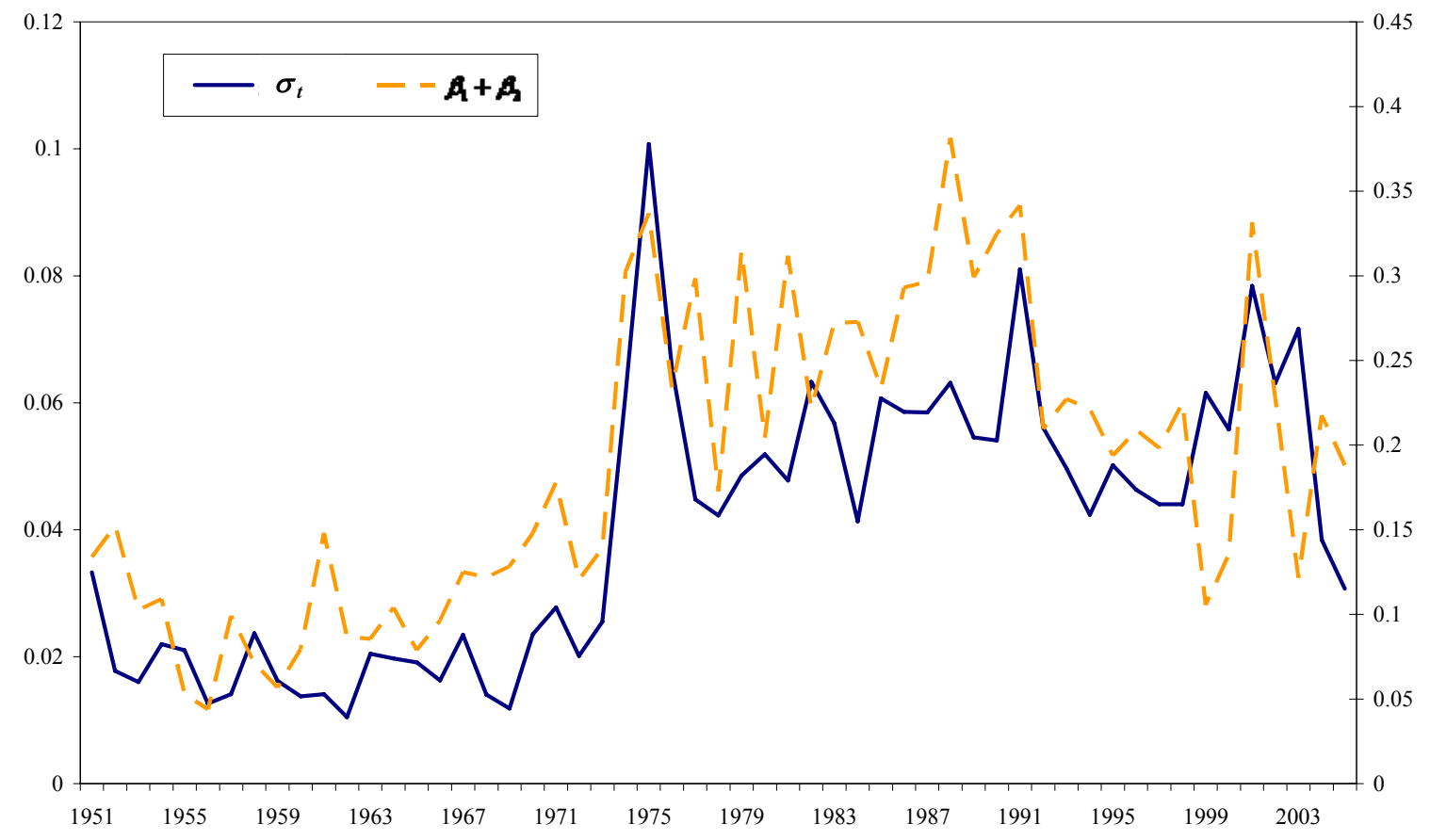

Figure 5 plots the time series equal-weighted raw dispersion and the slope coefficient of earnings on negative return in Basu (1997). The raw dispersion, $\sigma_{t}$, is the standard deviation of equalweighted earnings change per share $\left(\Delta X_{t} / P_{t-1}\right)$ for all sample firms in year $t$. We estimate $\beta_{1}+\beta_{1}$ from the following regression $X_{j, t} / P_{j, t-1}=\alpha_{0}+\alpha_{1} D R_{j, t}+\beta_{1} R_{j, t}+\beta_{2} R_{j, t} * D R_{j, t}+\varepsilon_{j, t}$, where $X_{j, t} / P_{j, t-1}$ is market-adjusted earnings deflated by the price at the beginning of fiscal year $t, R_{j, t}$ is the market-adjusted return for firm $j$ in year $t$, and $D R_{j, t}$ is a dummy variable for negative return firm-year observations. The scale of the left vertical axis is for $\sigma_{t}$, and scale of the right vertical axis is for the Basu coefficient, $\beta_{1}+\beta_{1}$. 
Table 1

Descriptive Statistics

This table presents summary statistics of key variables. $X_{t} / X_{t-1}$ measures the aggregate earnings growth. $O I_{t} / O I_{t-1}$ measures the aggregate operating income growth. $G D P_{t} / G D P_{t-1}$ measures the real GDP growth. $X_{t}$ is the aggregate total net income before extraordinary items (Compustat $\# 18$ ) in year t. $O I_{t}$ is the aggregate operating income after depreciation (Compustat \#178) in year t. $R_{t_{-}} e w$ is the equal-weighted buy and hold monthly market return from April of year $t$ to March of year $t+1 . R_{t_{-}} v w$ is the value-weighted buy and hold monthly market return from April of year $t$ to March of year $t+1$. The earnings growth and returns data in Panel B are extracted from Wilson and Jones (2002). The year 1933 was excluded as an outlier. The GDP data in Panel B pre-1929 is the GNP figures estimated by Romer (1989).

Panel A Descriptive statistics using Compustat data (1952-2006)

\begin{tabular}{|c|c|c|c|c|c|c|c|}
\hline & Mean & Std. Dev & Median & Min & Q1 & Q3 & Max \\
\hline$X_{t} / X_{t-1}$ & 1.123 & 0.268 & 1.125 & 0.359 & 1.009 & 1.188 & 2.668 \\
\hline$O I_{t} / O I_{t-1}$ & 1.111 & 0.134 & 1.124 & 0.832 & 1.026 & 1.180 & 1.523 \\
\hline$G D P_{t} / G D P_{t-1}$ & 1.033 & 0.022 & 1.034 & 0.981 & 1.023 & 1.046 & 1.072 \\
\hline$R_{t} e w$ & 0.170 & 0.226 & 0.128 & -0.192 & 0.038 & 0.292 & 0.998 \\
\hline$R_{t \_} v w$ & 0.130 & 0.170 & 0.150 & -0.279 & 0.004 & 0.253 & 0.503 \\
\hline \multicolumn{8}{|c|}{ Panel B Historical data (1872-1999) } \\
\hline & Mean & Std. Dev & Median & Min & Q1 & Q3 & Max \\
\hline$X_{t} / X_{t-1}$ & 1.066 & 0.278 & 1.063 & 0.125 & 0.910 & 1.200 & 2.400 \\
\hline$G D P_{t} / G D P_{t-1}$ & 1.040 & 0.062 & 1.038 & 0.832 & 1.012 & 1.065 & 1.227 \\
\hline$R_{t}$ & 0.107 & 0.181 & 0.107 & -0.452 & -0.008 & 0.240 & 0.502 \\
\hline
\end{tabular}


Table 2

Aggregate Earnings (Operating Income) Growth and Returns

This table presents the time series regression results for contemporaneous and lagged returns on the aggregate earnings growth and operating income growth. Panel A reports the result using the sample period from 1952 to 2006 and Panel B reports the result using the same sample period excluding 2001-2003. The dependent variables are equal-weighted contemporaneous $\left(R_{t}\right)$ and lagged $\left(R_{t-1}\right)$ returns in year $t . R_{t}$ ew is the equal-weighted buy and hold monthly market return from April of year $t$ to March of year $t+1 . R_{t} v w$ is the value-weighted buy and hold monthly market return from April of year $t$ to March of year $t+1$. The independent variables are aggregate earnings growth $\left(X_{t} / X_{t-1}\right)$ and aggregate operating income growth $\left(O I_{t} / O I_{t-1}\right) . X_{t}$ is the aggregate total net income before extraordinary items (Compustat \#18) in year t. $\mathrm{OI}_{t}$ is the aggregate operating income after depreciation (Compustat \#178) in year t. $t$-statistics is reported in parenthesis. The earnings growth and returns data in Panel C are extracted from Wilson and Jones (2002). The year 1933 was excluded as an outlier. The GDP data in Panel B pre-1929 is the GNP figures estimated by Romer (1989).

Panel A Sample period from 1952 to 2006

\begin{tabular}{|c|c|c|c|c|c|c|c|c|}
\hline \multirow[b]{2}{*}{ Intercept } & \multicolumn{2}{|c|}{$R_{t \_} e w$} & \multicolumn{2}{|c|}{$R_{t-1 \_ \text {ew }}$} & \multicolumn{2}{|c|}{$R_{t \_v w}$} & \multicolumn{2}{|c|}{$R_{t-1 \_} v w$} \\
\hline & $\begin{array}{c}-0.055 \\
(-0.414)\end{array}$ & $\begin{array}{c}0.661 \\
(2.502)\end{array}$ & $\begin{array}{c}0.128 \\
(0.939)\end{array}$ & $\begin{array}{c}-0.475 \\
(-1.844)\end{array}$ & $\begin{array}{c}0.089 \\
(0.879)\end{array}$ & $\begin{array}{c}0.241 \\
(1.242)\end{array}$ & $\begin{array}{c}0.143 \\
(1.403)\end{array}$ & $\begin{array}{c}-0.300 \\
(-1.603)\end{array}$ \\
\hline$X_{t} / X_{t-1}$ & $\begin{array}{c}0.197 \\
(1.725)\end{array}$ & & $\begin{array}{c}0.033 \\
(0.277)\end{array}$ & & $\begin{array}{c}0.035 \\
(0.398)\end{array}$ & & $\begin{array}{c}-0.011 \\
(-0.128)\end{array}$ & \\
\hline$O I_{t} / O I_{t-1}$ & & $\begin{array}{c}-0.442 \\
(-1.881)\end{array}$ & & $\begin{array}{c}0.572 \\
(2.500) \\
\end{array}$ & & $\begin{array}{c}-0.101 \\
(-0.585)\end{array}$ & & $\begin{array}{c}0.387 \\
(2.319) \\
\end{array}$ \\
\hline$R^{2}$ & 0.037 & 0.047 & -0.018 & 0.092 & -0.016 & -0.012 & -0.018 & 0.074 \\
\hline
\end{tabular}

Panel B Sample period from 1952 to 2006, excluding 2001-2003

\begin{tabular}{|c|c|c|c|c|c|c|c|c|}
\hline \multirow[b]{2}{*}{ Intercept } & \multicolumn{2}{|c|}{$R_{t \_} e w$} & \multicolumn{2}{|c|}{$R_{t-1}$ ew } & \multicolumn{2}{|c|}{$R_{t \_v w}$} & \multicolumn{2}{|c|}{$R_{t-1 \_} v w$} \\
\hline & $\begin{array}{c}0.689 \\
(3.059)\end{array}$ & $\begin{array}{c}0.765 \\
(3.312)\end{array}$ & $\begin{array}{c}-0.340 \\
(-1.297)\end{array}$ & $\begin{array}{c}-0.449 \\
(-1.678)\end{array}$ & $\begin{array}{c}0.483 \\
(2.575)\end{array}$ & $\begin{array}{c}0.360 \\
(1.890)\end{array}$ & $\begin{array}{c}-0.284 \\
(-1.545)\end{array}$ & $\begin{array}{c}-0.256 \\
(-1.386)\end{array}$ \\
\hline$X_{t} / X_{t-1}$ & $\begin{array}{c}-0.480 \\
(-2.380)\end{array}$ & & $\begin{array}{c}0.465 \\
(1.982)\end{array}$ & & $\begin{array}{c}-0.314 \\
(-1.866)\end{array}$ & & $\begin{array}{c}0.390 \\
(2.357)\end{array}$ & \\
\hline$O I_{t} / O I_{t-1}$ & & $\begin{array}{c}-0.542 \\
(-2.651)\end{array}$ & & $\begin{array}{c}0.558 \\
(2.351)\end{array}$ & & $\begin{array}{c}-0.202 \\
(-1.189) \\
\end{array}$ & & $\begin{array}{c}0.360 \\
(2.194)\end{array}$ \\
\hline$R^{2}$ & 0.087 & 0.110 & 0.056 & 0.085 & 0.046 & 0.008 & 0.081 & 0.068 \\
\hline
\end{tabular}

Panel C Sample Period 1872 - 1999

\begin{tabular}{|c|c|c|c|c|}
\hline & \multicolumn{2}{|c|}{ Years 1934 - 1999} & \multicolumn{2}{|c|}{ Years $1872-1932$} \\
\hline \multirow{3}{*}{ Intercept } & $R_{t}$ & $R_{t-1}$ & $R_{t}$ & $R_{t-1}$ \\
\hline & 0.320 & -0.250 & -0.189 & -0.240 \\
\hline & $(3.12)$ & $(-1.97)$ & $(-2.58)$ & $(-2.55)$ \\
\hline \multirow[t]{2}{*}{$X_{t} / X_{t-1}$} & -0.166 & 0.357 & 0.255 & 0.307 \\
\hline & $(-1.79)$ & $(3.11)$ & $(4.06)$ & $(3.20)$ \\
\hline$R^{2}$ & 0.022 & 0.143 & 0.202 & 0.304 \\
\hline
\end{tabular}


Table 3

Aggregate Earnings (Operating Income) Growth, GDP Growth, and Industrial Production

This table presents the time series regression results for the aggregate earnings growth and operating income growth on the contemporaneous and lagged growth of real GDP. Panel A reports the result using the sample period from 1952 to 2006 and Panel B reports the result using the sample period excluding 2001-2003. The dependent variables are aggregate earnings growth $\left(X_{t}\right.$ $\left./ X_{t-1}\right)$ and aggregate operating income growth $\left(O I_{t} / O I_{t-1}\right) . X_{t}$ is the aggregate total net income before extraordinary items (Compustat \#18) in year t. $O I_{t}$ is the aggregate operating income after depreciation (Compustat \#178) in year t. The independent variables are contemporaneous growth in real GDP $\left(G D P_{t} / G D P_{t-1}\right)$ and industry production $\left(P R O D_{t} / P R O D_{t-1}\right)$ in year $t$. $t$-statistics is reported in parenthesis. The earnings growth and returns data in Panel $\mathrm{C}$ are extracted from Wilson and Jones (2002). The year 1933 was excluded as an outlier. The GDP data in Panel B pre-1929 is the GNP figures estimated by Romer (1989).

Panel A Sample period from 1952 to 2006

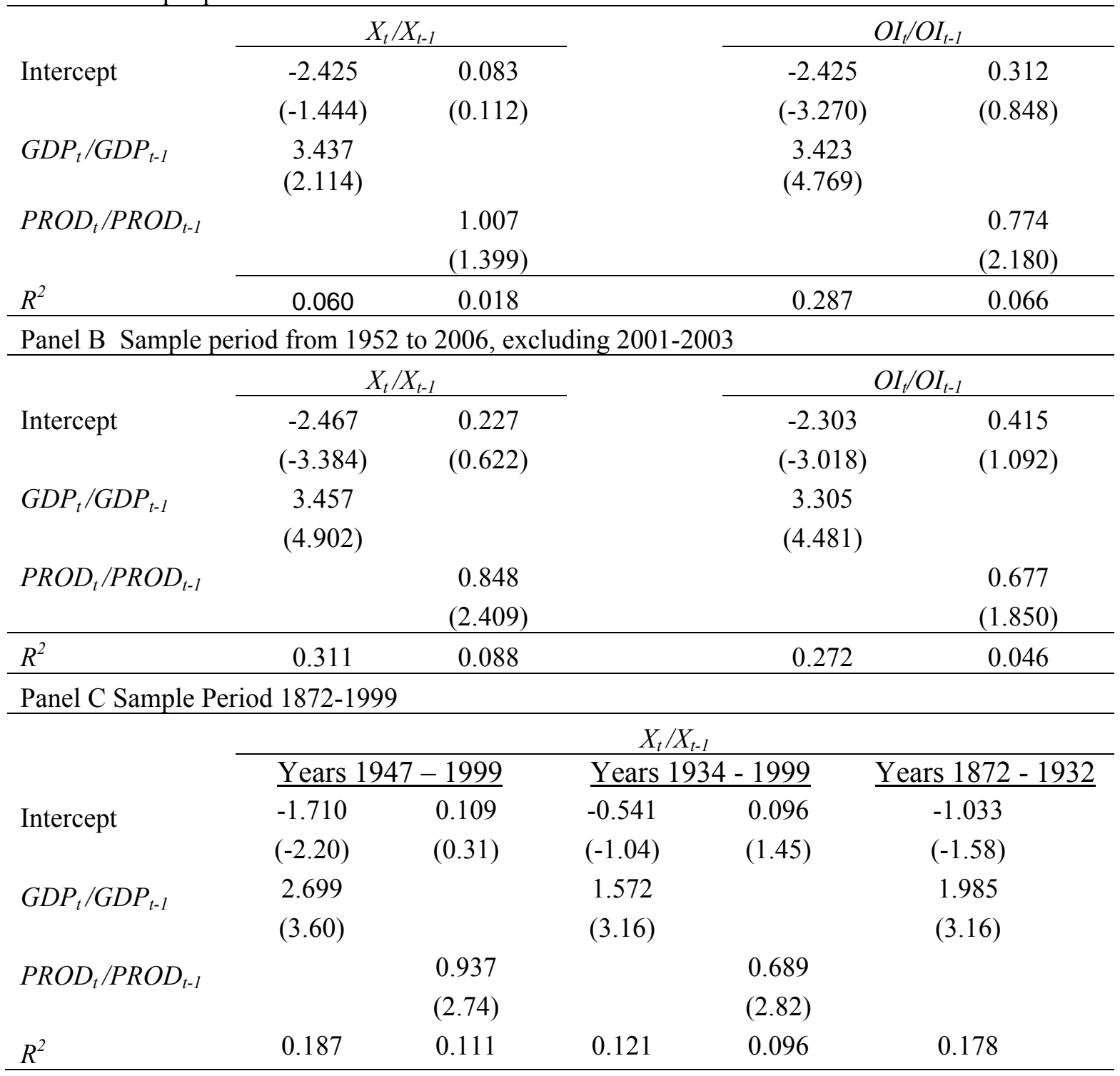


Table 4

Aggregate Earnings (Operating Income) Growth and Returns, Pre- and Post-FASB

This table presents the time series regression results for contemporaneous and lagged returns on the aggregate earnings growth and operating income growth, incorporating the pre and post FASB effect. The sample in this table only covers the period from 1952 to 2006 excluding 2001-2003. Panel A uses equal-weighted returns and Panel B uses value-weighted returns. $R_{t_{-}} e w$ is calculated as the equal-weighted buy and hold monthly market return from April of year $t$ to March of year $t+1 . R_{t_{-}} v w$ is calculated as the value-weighted buy and hold monthly market return from April of year $t$ to March of year $t+1$. The independent variables are aggregate earnings growth $\left(X_{t} / X_{t-1}\right)$ and aggregate operating income growth $\left(O I_{t} / O I_{t-1}\right) . X_{t}$ is the aggregate total net income before extraordinary items (Compustat \#18) in year t. $O I_{t}$ is the aggregate operating income after depreciation (Compustat \#178) in year t. $D_{1973}$ is a dummy variable which equals 1 for years after 1973 and 0 otherwise. $t$-statistics is reported in parenthesis.

\begin{tabular}{|c|c|c|c|c|}
\hline \multicolumn{5}{|c|}{ Panel A Equal-weighted returns } \\
\hline \multirow{3}{*}{ Intercept } & \multicolumn{2}{|c|}{$R_{t} e w$} & \multicolumn{2}{|c|}{$R_{t-1 \_e w}$} \\
\hline & 0.852 & 0.554 & -0.583 & -0.493 \\
\hline & $(1.795)$ & $(1.975)$ & $(-1.059)$ & $(-1.506)$ \\
\hline \multirow[t]{2}{*}{$D_{1973}$} & -0.208 & 0.690 & 0.322 & -0.066 \\
\hline & $(-0.384)$ & $(1.331)$ & $(0.514)$ & $(-0.109)$ \\
\hline \multirow[t]{2}{*}{$X_{t} / X_{t-1}$} & -0.644 & & 0.656 & \\
\hline & $(-1.515)$ & & $(1.331)$ & \\
\hline \multirow[t]{2}{*}{$X_{t} / X_{t-1} * D_{1973}$} & 0.217 & & -0.242 & \\
\hline & $(0.447)$ & & $(-0.429)$ & \\
\hline \multirow[t]{2}{*}{$O I_{t} / O I_{t-1}$} & & -0.366 & & 0.560 \\
\hline & & $(-1.507)$ & & $(1.974)$ \\
\hline \multirow[t]{2}{*}{$O I_{t} / O I_{t-1} * D_{1973}$} & & -0.603 & & 0.124 \\
\hline & & $(-1.305)$ & & $(0.230)$ \\
\hline$R^{2}$ & 0.058 & 0.106 & 0.034 & 0.072 \\
\hline \multicolumn{5}{|c|}{ Panel B Value-weighted returns } \\
\hline \multirow{3}{*}{ Intercept } & & & & \\
\hline & 0.582 & 0.137 & -0.826 & -0.339 \\
\hline & $(1.522)$ & $(0.620)$ & $(-2.255)$ & $(-1.531)$ \\
\hline \multirow[t]{2}{*}{$D_{1973}$} & -0.121 & 0.803 & 0.722 & 0.269 \\
\hline & $(-0.275)$ & $(1.860)$ & $(1.708)$ & $(0.625)$ \\
\hline \multirow[t]{2}{*}{$X_{t} / X_{t-1}$} & -0.420 & & 0.876 & \\
\hline & $(-1.216)$ & & $(2.647)$ & \\
\hline \multirow[t]{2}{*}{$X_{t} / X_{t-1} * D_{1973}$} & 0.137 & & -0.645 & \\
\hline & $(0.346)$ & & $(-1.694)$ & \\
\hline \multirow[t]{2}{*}{$O I_{t} / O I_{t-1}$} & & -0.017 & & 0.424 \\
\hline & & $(-0.085)$ & & (2.189) \\
\hline \multirow[t]{2}{*}{$O I_{t} / O I_{t-1} * D_{1973}$} & & -0.700 & & -0.224 \\
\hline & & $(-1.813)$ & & $(-0.581)$ \\
\hline$R^{2}$ & 0.018 & 0.038 & 0.097 & 0.041 \\
\hline
\end{tabular}


Table 5

Aggregate Earnings (Operating Income) Growth and GDP growth, Pre- and Post-FASB

This table presents the time series regression results for contemporaneous and lagged returns on the aggregate earnings growth and operating income growth, incorporating the pre and post FASB effect. The sample in this table only covers the period excluding 2001-2003. The dependent variables are equal-weighted contemporaneous $\left(R_{t}\right)$ and lagged $\left(R_{t-1}\right)$ returns in year $t$. $R_{t}$ is the buy and hold monthly market return from April of year $t$ to March of year $t+1$. The independent variables are aggregate earnings growth $\left(X_{t} / X_{t-1}\right)$ and aggregate operating income growth $\left(O I_{t} / O I_{t-1}\right) . X_{t}$ is the aggregate total net income before extraordinary items (Compustat \#18) in year t. $O I_{t}$ is the aggregate operating income after depreciation (Compustat \#178) in year t. $D_{1973}$ is a dummy variable which equals 1 for years after 1973 and 0 otherwise. The independent variables are contemporaneous growth in real GDP $\left(G D P_{t} / G D P_{t-1}\right)$ and industry production $\left(P R O D_{t} / P R O D_{t-1}\right)$ in year $t . t$-statistics is reported in parenthesis.

\begin{tabular}{|c|c|c|c|c|}
\hline \multirow{3}{*}{ Intercept } & \multicolumn{2}{|c|}{$X_{t} / X_{t-1}$} & \multicolumn{2}{|c|}{$O I_{t} / O I_{t-1}$} \\
\hline & -2.153 & 0.670 & -3.652 & 0.145 \\
\hline & $(-2.062)$ & $(1.404)$ & $(-3.420)$ & $(0.286)$ \\
\hline \multirow[t]{2}{*}{$D_{1973}$} & -0.856 & -1.202 & 2.775 & 0.735 \\
\hline & $(-0.572)$ & $(-1.591)$ & $(1.815)$ & $(0.917)$ \\
\hline \multirow[t]{2}{*}{$G D P_{t} / G D P_{t-1}$} & 3.140 & & 4.605 & \\
\hline & $(3.122)$ & & $(4.477)$ & \\
\hline \multirow[t]{2}{*}{$G D P_{t} / G D P_{t-1} * D_{1973}$} & 0.852 & & -2.682 & \\
\hline & $(0.589)$ & & $(-1.815)$ & \\
\hline \multirow[t]{2}{*}{$\mathrm{PROD}_{t} / \mathrm{PROD}_{t-1}$} & & 0.418 & & 0.940 \\
\hline & & $(0.918)$ & & $(1.950)$ \\
\hline \multirow[t]{2}{*}{$P_{R O D} / P_{R O D} * D_{1973}$} & & 1.176 & & -0.719 \\
\hline & & $(1.612)$ & & $(-0.930)$ \\
\hline$R^{2}$ & 0.297 & 0.102 & 0.291 & 0.025 \\
\hline
\end{tabular}


Table 6

Basu Regression Pre and Post FASB

This table reports the Basu regression with pre and post FASB effect. Panel A reports the aggregate level regression results using the equal-weighted return. Panel B reports the aggregate level regression results using the value-weighted return. $R_{t-}$ ew is the equal-weighted buy and hold monthly market return from April of year $t$ to March of year $t+1 . R_{t_{-}} v w$ is the value-weighted buy and hold monthly market return from April of year $t$ to March of year $t+1$.DR is a dummy variable which equals 1 if $R_{t_{-}} e w<0\left(\right.$ or $\left.R_{t_{-}} v w<0\right)$ and 0 otherwise. The independent variables are aggregate earnings scaled by the beginning aggregate market value $\left(X_{t} / P_{t-1}\right)$ and aggregate operating income scaled by the beginning aggregate market value $\left(O I_{t} / P_{t-1}\right) . X_{t}$ is the aggregate total net income before extraordinary items (Compustat \#18) in year t. $O I_{t}$ is the aggregate operating income after depreciation (Compustat \#178) in year t. $D_{1973}$ is a dummy variable which equals 1 for years after 1973 and 0 otherwise. The earnings growth and returns data in Panel C and D are extracted Wilson and Jones (2002). The year 1933 was excluded as an outlier. The GDP data in Panel B pre-1929 is the GNP figures estimated by Romer (1989).

Panel A Basu-Regression at the aggregate level (equal-weighted returns)

\begin{tabular}{|c|c|c|c|c|}
\hline \multirow[b]{2}{*}{ Intercept } & \multicolumn{2}{|c|}{$X_{t} / P_{t-1}$} & \multicolumn{2}{|c|}{$O I_{t} / P_{t-1}$} \\
\hline & $\begin{array}{c}0.088 \\
(9.106)\end{array}$ & $\begin{array}{c}0.074 \\
(5.227)\end{array}$ & $\begin{array}{c}0.176 \\
(7.677)\end{array}$ & $\begin{array}{c}0.120 \\
(4.590)\end{array}$ \\
\hline$D R$ & $\begin{array}{c}0.005 \\
(0.107)\end{array}$ & $\begin{array}{c}-0.015 \\
(-0.301)\end{array}$ & $\begin{array}{c}0.018 \\
(0.177)\end{array}$ & $\begin{array}{c}-0.010 \\
(-0.109)\end{array}$ \\
\hline$R_{t} e w$ & $\begin{array}{c}0.027 \\
(0.759)\end{array}$ & $\begin{array}{c}0.008 \\
(0.134)\end{array}$ & $\begin{array}{c}0.066 \\
(0.772)\end{array}$ & $\begin{array}{c}-0.022 \\
(-0.198)\end{array}$ \\
\hline$R_{t \_} e w * D R$ & $\begin{array}{c}0.071 \\
(0.214)\end{array}$ & $\begin{array}{c}-0.091 \\
(-0.255)\end{array}$ & $\begin{array}{c}0.084 \\
(0.107)\end{array}$ & $\begin{array}{c}-0.234 \\
(-0.360)\end{array}$ \\
\hline$D_{1973}$ & & $\begin{array}{c}0.030 \\
(1.576)\end{array}$ & & $\begin{array}{c}0.122 \\
(3.569)\end{array}$ \\
\hline$D R^{*} D_{1973}$ & & $\begin{array}{c}0.089 \\
(0.904)\end{array}$ & & $\begin{array}{c}0.154 \\
(0.854)\end{array}$ \\
\hline$R_{t_{-}} e w * D_{1973}$ & & $\begin{array}{c}0.010 \\
(0.130)\end{array}$ & & $\begin{array}{c}0.051 \\
(0.376)\end{array}$ \\
\hline$R_{t \_} e w * D R^{*} D_{1973}$ & & $\begin{array}{c}0.818 \\
(1.045) \\
\end{array}$ & & $\begin{array}{c}1.745 \\
(1.218) \\
\end{array}$ \\
\hline$R^{2}$ & -0.029 & 0.081 & -0.045 & 0.442 \\
\hline
\end{tabular}


Panel B Basu-Regression at the aggregate level (value-weighted returns)

\begin{tabular}{|c|c|c|c|c|}
\hline \multirow[b]{2}{*}{ Intercept } & \multicolumn{2}{|c|}{$X_{t} / P_{t-1}$} & \multicolumn{2}{|c|}{$O I_{t} / P_{t-1}$} \\
\hline & $\begin{array}{c}0.082 \\
(7.103)\end{array}$ & $\begin{array}{c}0.071 \\
(4.841)\end{array}$ & $\begin{array}{c}0.166 \\
(6.121)\end{array}$ & $\begin{array}{c}0.123 \\
(4.453)\end{array}$ \\
\hline$D R$ & $\begin{array}{c}0.006 \\
(0.263)\end{array}$ & $\begin{array}{c}-0.031 \\
(-0.528)\end{array}$ & $\begin{array}{c}0.016 \\
(0.302)\end{array}$ & $\begin{array}{c}-0.086 \\
(-0.793)\end{array}$ \\
\hline$R_{t} v w w$ & $\begin{array}{c}0.058 \\
(1.156)\end{array}$ & $\begin{array}{c}0.030 \\
(0.457)\end{array}$ & $\begin{array}{c}0.119 \\
(1.001)\end{array}$ & $\begin{array}{c}-0.012 \\
(-0.100)\end{array}$ \\
\hline$R_{t-} v w * D R$ & $\begin{array}{c}-0.029 \\
(-0.180)\end{array}$ & $\begin{array}{c}-0.264 \\
(-0.574)\end{array}$ & $\begin{array}{c}-0.048 \\
(-0.125)\end{array}$ & $\begin{array}{c}-0.679 \\
(-0.789)\end{array}$ \\
\hline$D_{1973}$ & & $\begin{array}{c}0.020 \\
(0.890)\end{array}$ & & $\begin{array}{c}0.083 \\
(2.000)\end{array}$ \\
\hline$D R^{*} D_{1973}$ & & $\begin{array}{c}0.039 \\
(0.612)\end{array}$ & & $\begin{array}{c}0.103 \\
(0.862)\end{array}$ \\
\hline$R_{t \_} v w * D_{1973}$ & & $\begin{array}{c}0.038 \\
(0.392)\end{array}$ & & $\begin{array}{c}0.184 \\
(1.008)\end{array}$ \\
\hline$R_{t} v w^{*} D R^{*} D_{1973}$ & & $\begin{array}{c}0.211 \\
(0.427) \\
\end{array}$ & & $\begin{array}{c}0.507 \\
(0.549) \\
\end{array}$ \\
\hline$R^{2}$ & -0.024 & 0.055 & -0.035 & 0.402 \\
\hline
\end{tabular}


Panel C Aggregate Basu Regressions 1933 - 1999 (Dependent Variable: Aggregate Earnings Growth)

\begin{tabular}{|c|c|c|}
\hline & $1933-1999$ & $1974-1999$ \\
\hline Intercept & $\begin{array}{c}1.206 \\
(23.66)\end{array}$ & $\begin{array}{c}1.297 \\
(21.23)\end{array}$ \\
\hline$D R$ & $\begin{array}{l}-0.120 \\
(-1.15)\end{array}$ & $\begin{array}{l}-0.300 \\
(-2.60)\end{array}$ \\
\hline$R_{i, t}$ & $\begin{array}{l}-0.539 \\
(-2.47)\end{array}$ & $\begin{array}{l}-0.979 \\
(-3.81)\end{array}$ \\
\hline$R_{i, t} * D R$ & $\begin{array}{l}0.445 \\
(0.66) \\
\end{array}$ & $\begin{array}{l}0.578 \\
(0.78) \\
\end{array}$ \\
\hline$R^{2}$ & 0.046 & 0.331 \\
\hline
\end{tabular}

Panel D Aggregate Basu Regressions 1933 - 1999 (Dependent Variable: Aggregate Earnings Scaled by Beginning Aggregate Market Value)

\begin{tabular}{|c|c|c|}
\hline & $1933-1999$ & $1974-1999$ \\
\hline Intercept & $\begin{array}{c}0.078 \\
(10.28)\end{array}$ & $\begin{array}{l}0.081 \\
(5.21)\end{array}$ \\
\hline$D R$ & $\begin{array}{l}-0.000 \\
(-0.01)\end{array}$ & $\begin{array}{l}0.013 \\
(0.20)\end{array}$ \\
\hline$R_{i, t}$ & $\begin{array}{l}0.018 \\
(0.55)\end{array}$ & $\begin{array}{l}0.009 \\
(0.30)\end{array}$ \\
\hline$R_{i, t} * D R$ & $\begin{array}{c}0.009 \\
(0.09)\end{array}$ & $\begin{array}{l}-0.033 \\
(-0.17) \\
\end{array}$ \\
\hline$R^{2}$ & -0.032 & -0.124 \\
\hline
\end{tabular}


Table 7

Summary Statistics for firm-level Basu-Regression

This table presents the summary statistics for the parameter estimation results of the time series Basuregression at the individual firm level. The time series regression is conducted for each firm with more than 20 observations in either pre-FASB period or post-FASB period. $R_{i, t}$ is the buy and hold monthly return for firm $i$ from April of year $t$ to March of year $t+1$. DR is a dummy variable which equals 1 if $R_{i, t}<0$ and 0 otherwise. The independent variables are aggregated earnings deflated by the beginning market value $\left(X_{i, t} / P_{i, t-1}\right)$ and aggregated operating income deflated by the beginning market value $\left(O I_{i, t}\right.$ $\left./ P_{i, t-1}\right) . X_{i, t}$ is the net income before extraordinary items (Compustat \#18) for firm $i$ in year t. $O I_{i, t}$ is the operating income after depreciation (Compustat \#178) for firm $i$ in year $\mathrm{t}$. The $t$-statistics reported in parenthesis in the mean column is the result from two sample t-test of coefficients of the pre- and post-FASB samples.

Panel A Dependent variable $X_{i, t} / P_{i, t-1}$

\begin{tabular}{|c|c|c|c|c|c|c|c|}
\hline & \multicolumn{7}{|c|}{ Pre-FASB period, 219 firms in the sample } \\
\hline & Mean & Std & Median & Min & P25 & P75 & Max \\
\hline Intercept & 0.081 & 0.027 & 0.077 & 0.015 & 0.065 & 0.099 & 0.173 \\
\hline$D R$ & -0.005 & 0.038 & -0.001 & -0.209 & -0.014 & 0.010 & 0.102 \\
\hline$R_{i, t}$ & 0.047 & 0.053 & 0.045 & -0.164 & 0.016 & 0.080 & 0.182 \\
\hline \multirow[t]{3}{*}{$R_{i, t} * D R$} & 0.034 & 0.131 & 0.031 & -0.651 & -0.044 & 0.106 & 0.367 \\
\hline & \multicolumn{7}{|c|}{ Post-FASB period, 1079 firms in the sample } \\
\hline & Mean & Std & Median & Min & P25 & P75 & Max \\
\hline Intercept & 0.081 & 0.062 & 0.084 & -0.289 & 0.056 & 0.115 & 0.365 \\
\hline$D R$ & 0.000 & 0.085 & 0.000 & -0.465 & -0.036 & 0.034 & 0.572 \\
\hline$R_{i, t}$ & 0.048 & 0.115 & 0.045 & -0.634 & 0.002 & 0.095 & 0.861 \\
\hline$R_{i, t} * D R$ & 0.094 & 0.372 & 0.065 & -1.516 & -0.080 & 0.245 & 2.306 \\
\hline
\end{tabular}

Panel B Dependent variable $O I_{i, t} / P_{i, t-1}$

\begin{tabular}{|c|c|c|c|c|c|c|c|}
\hline & \multicolumn{7}{|c|}{ Pre-FASB period, 219 firms in the sample } \\
\hline & Mean & Std & Median & Min & $\mathrm{P} 25$ & P75 & Max \\
\hline Intercept & 0.162 & 0.064 & 0.152 & 0.009 & 0.122 & 0.201 & 0.365 \\
\hline$D R$ & -0.012 & 0.069 & -0.007 & -0.281 & -0.039 & 0.025 & 0.209 \\
\hline$R_{i, t}$ & 0.089 & 0.112 & 0.086 & -0.255 & 0.023 & 0.149 & 0.578 \\
\hline \multirow[t]{3}{*}{$R_{i, t} * D R$} & 0.069 & 0.266 & 0.056 & -1.082 & -0.061 & 0.236 & 0.949 \\
\hline & \multicolumn{7}{|c|}{ Post-1973 period, 1079 firms in the sample } \\
\hline & Mean & Std & Median & Min & $\mathrm{P} 25$ & P75 & Max \\
\hline Intercept & 0.180 & 0.116 & 0.168 & -0.224 & 0.109 & 0.245 & 0.865 \\
\hline$D R$ & -0.003 & 0.115 & -0.003 & -0.647 & -0.058 & 0.046 & 1.091 \\
\hline$R_{i, t}$ & 0.111 & 0.164 & 0.087 & -0.541 & 0.019 & 0.187 & 1.155 \\
\hline$R_{i, t} * D R$ & 0.029 & 0.603 & 0.038 & -8.150 & -0.161 & 0.267 & 5.756 \\
\hline
\end{tabular}


Table 8

Persistence of Earnings Pre and Post FASB

This table reports the results of persistence of earnings with the pre and post FASB effect, conditional on 'earnings news'. Panel A presents the time-series regression results at the aggregate level. Panel B This table presents the summary statistics for the parameter estimation results of the time-series regression at the individual firm level.

Panel A Earnings persistence at the aggregate level

$\Delta X_{t} / P_{t-1}$ is the aggregated total net income change deflated by the beginning market value and $\Delta O I_{t} / P_{t-1}$ is the aggregated operating income change deflated by the beginning market value in period t.. $X_{t}$ is the aggregate total net income before extraordinary items (Compustat \#18) in year t. $\mathrm{OI}_{t}$ is the aggregate operating income after depreciation (Compustat \#178) in year t. $D$ is a dummy variable which equals 1 if $\Delta X_{t-1} / P_{t-2}<0$ (or $\Delta O I_{t-1} / P_{t-2}<0$ ) and 0 otherwise. $D_{1973}$ is a dummy variable which equals 1 for years after 1973 and 0 otherwise.

\begin{tabular}{|c|c|c|c|c|c|}
\hline \multirow[b]{2}{*}{ Intercept } & \multicolumn{2}{|c|}{$\Delta X_{t} / P_{t-1}$} & \multirow[b]{2}{*}{ Intercept } & \multicolumn{2}{|c|}{$\Delta O I_{t} / P_{t-1}$} \\
\hline & $\begin{array}{l}0.005 \\
(1.51)\end{array}$ & $\begin{array}{l}0.002 \\
(0.36)\end{array}$ & & $\begin{array}{l}0.011 \\
(2.14)\end{array}$ & $\begin{array}{l}0.007 \\
(0.74)\end{array}$ \\
\hline$D$ & $\begin{array}{l}0.003 \\
(0.44)\end{array}$ & $\begin{array}{l}0.002 \\
(0.24)\end{array}$ & $D$ & $\begin{array}{l}0.004 \\
(0.25)\end{array}$ & $\begin{array}{l}0.001 \\
(0.05)\end{array}$ \\
\hline$\Delta X_{t-1} / P_{t-2}$ & $\begin{array}{l}0.207 \\
(1.11)\end{array}$ & $\begin{array}{l}0.579 \\
(0.91)\end{array}$ & $\Delta O I_{t-1} / P_{t-2}$ & $\begin{array}{l}0.162 \\
(0.85)\end{array}$ & $\begin{array}{l}0.089 \\
(0.21)\end{array}$ \\
\hline$\Delta X_{t-1} / P_{t-2} * D$ & $\begin{array}{l}-0.265 \\
(-0.45)\end{array}$ & $\begin{array}{l}-1.668 \\
(-0.86)\end{array}$ & $\Delta O I_{t-1} / P_{t-2} * D$ & $\begin{array}{l}-0.663 \\
(-0.66)\end{array}$ & $\begin{array}{l}-0.755 \\
(-0.57)\end{array}$ \\
\hline$D_{1973}$ & & $\begin{array}{l}0.005 \\
(0.72)\end{array}$ & $D_{1973}$ & & $\begin{array}{l}0.010 \\
(0.90)\end{array}$ \\
\hline$D^{*} D_{1973}$ & & $\begin{array}{c}0.033 \\
(0.904)\end{array}$ & $D^{*} D_{1973}$ & & $\begin{array}{l}0.022 \\
(0.57)\end{array}$ \\
\hline$\Delta X_{t-1} / P_{t-2} * D_{1973}$ & & $\begin{array}{l}-0.462 \\
(-0.68)\end{array}$ & $\Delta O I_{t-1} / P_{t-2} * D_{1973}$ & & $\begin{array}{l}0.005 \\
(0.01)\end{array}$ \\
\hline$\Delta X_{t-1} / P_{t-2} * D^{*} D_{1973}$ & & $\begin{array}{l}2.812 \\
(1.44) \\
\end{array}$ & $\Delta O I_{t-1} / P_{t-2} * D^{*} D_{1973}$ & & $\begin{array}{l}1.038 \\
(0.48) \\
\end{array}$ \\
\hline$R^{2}$ & -0.034 & 0.088 & $R^{2}$ & -0.021 & -0.026 \\
\hline
\end{tabular}


Panel B Earnings persistence at the firm level

This table presents the summary statistics for the parameter estimation results of earnings persistence at the individual firm level. The time series regression is conducted for each firm with more than 20 observations in either pre-FASB period or post-FASB period. $\Delta X_{i, t} / P_{i, t-1}$ is the change of net income deflated by the beginning market value for firm $i$ in year t. $\Delta O I_{i, t} / P_{i, t-1}$ is the change of operating income deflated by the beginning market value for firm $i$ in year t. $D$ is a dummy variable which equals 1 if $\Delta X_{i, t-1} / P_{i, t-2}<0$ (or $\Delta O I_{i, t-1} / P_{i, t-2}<0$ ) and 0 otherwise. The $t$ statistics reported in parenthesis in the mean column is the result from two sample t-test of coefficients of the pre- and post-FASB samples.

Persistence of Net Income $\Delta X_{i, t} / P_{i, t-1}$

\begin{tabular}{|c|c|c|c|c|c|c|c|}
\hline & \multicolumn{7}{|c|}{ Pre-FASB period, 213 firms in the sample } \\
\hline & Mean & Std & Median & Min & $\mathrm{P} 25$ & P75 & Max \\
\hline Intercept & -0.003 & 0.059 & 0.005 & -0.417 & -0.002 & 0.013 & 0.186 \\
\hline$D$ & -0.016 & 0.104 & -0.009 & -0.655 & -0.033 & 0.006 & 0.481 \\
\hline$\Delta X_{i, t-1} / P_{i, t-2}$ & -0.190 & 2.228 & 0.018 & -12.292 & -0.173 & 0.273 & 11.881 \\
\hline \multirow[t]{3}{*}{$\Delta X_{i, t-1} / P_{i, t-2} * D$} & -0.339 & 2.550 & -0.462 & -11.877 & -1.050 & 0.286 & 12.289 \\
\hline & \multicolumn{7}{|c|}{ Post-FASB period, 1027 firms in the sample } \\
\hline & Mean & Std & Median & Min & $\mathrm{P} 25$ & P75 & $\operatorname{Max}$ \\
\hline Intercept & -0.004 & 0.056 & 0.003 & -0.651 & -0.012 & 0.014 & 0.280 \\
\hline$D$ & -0.014 & 0.094 & -0.008 & -0.596 & -0.043 & 0.017 & 0.800 \\
\hline$\Delta X_{i, t-1} / P_{i, t-2}$ & 0.027 & 0.678 & 0.093 & -12.489 & -0.133 & 0.303 & 3.898 \\
\hline$\Delta X_{i, t-1} / P_{i, t-2} * D$ & -0.660 & 1.501 & -0.695 & -14.084 & -1.278 & -0.080 & 14.995 \\
\hline
\end{tabular}

Persistence of operating income $\Delta O I_{i, t} / P_{i, t-1}$

\begin{tabular}{lccccccc}
\hline \multicolumn{7}{c}{ Pre-FASB period, 214 firms in the sample } \\
\cline { 2 - 8 } & Mean & Std & Median & Min & P25 & P75 & Max \\
Intercept & -0.010 & 0.119 & 0.013 & -0.824 & 0.000 & 0.028 & 0.361 \\
$D$ & -0.014 & 0.156 & -0.020 & -0.586 & -0.066 & 0.017 & 0.924 \\
$\Delta O I_{i, t-1} / P_{i, t-2}$ & -0.119 & 2.461 & -0.019 & -13.370 & -0.303 & 0.264 & 14.979 \\
$\Delta O I_{i, t-1} / P_{i, t-2} * D$ & -0.368 & 2.729 & -0.450 & -14.978 & -1.068 & 0.297 & 13.372 \\
\hline \multicolumn{7}{c}{} \\
\cline { 2 - 8 } & Post-1973 period, 1156 firms in the sample & & & \\
\cline { 2 - 8 } & Mean & Std & Median & Min & P25 & P75 & Max \\
Intercept & 0.005 & 0.070 & 0.009 & -0.733 & -0.008 & 0.028 & 0.320 \\
$D$ & -0.014 & 0.140 & -0.007 & -2.107 & -0.047 & 0.025 & 0.919 \\
$\Delta O I_{i, t-1} / P_{i, t-2}$ & 0.094 & 0.723 & 0.146 & -11.920 & -0.090 & 0.367 & 6.410 \\
$\Delta O I_{i, t-1} / P_{i, t-2} * D$ & -0.589 & 1.428 & -0.514 & -8.296 & -1.166 & 0.000 & 12.452 \\
\hline
\end{tabular}


Table 9

Predictability of aggregate earnings on future cash flow, Pre and Post FASB

This table presents the time-series regression of predicting aggregate future cash flow. Panel A presents the results of predicting aggregate future cash flow growth, and Panel B presents the results of predicting aggregate future cash flow scaled by total assets. $C F O_{t}$ is the aggregate operating cash flow in period $t$, calculated as $X_{t}$ (net income before extraordinary items) $+D e p_{t}$ (Depreciation) $+\Delta D T_{t}$ (change in deferred tax)- $\Delta W C_{t}$ (change in working capital: $\Delta$ Current assets $+\Delta$ Debt in current liabilities- $\Delta$ Current liabilities- $\Delta$ Cash). $X_{t}$ is the aggregate net income before extraordinary items (Compustat \#18) in year $t$. OI $t_{t}$ is the aggregate operating income after depreciation (Compustat \#178) in year $t . P_{t}$ is the aggregate market value in year t. $t$-statistics is reported in parenthesis.

Panel A Predicting the aggregate future cash flow growth

\begin{tabular}{|c|c|c|c|c|c|}
\hline \multirow[b]{2}{*}{ Intercept } & \multicolumn{2}{|c|}{$C F O_{t+1} / C F O_{t}$} & \multirow[b]{2}{*}{ Intercept } & \multicolumn{2}{|c|}{$C F O_{t+1} / C F O_{t}$} \\
\hline & $\begin{array}{c}1.893 \\
(5.520)\end{array}$ & $\begin{array}{c}2.563 \\
(3.623)\end{array}$ & & $\begin{array}{c}1.963 \\
(5.896)\end{array}$ & $\begin{array}{c}2.073 \\
(5.070)\end{array}$ \\
\hline$D_{1973}$ & & $\begin{array}{c}-0.950 \\
(-1.078)\end{array}$ & $D_{1973}$ & & $\begin{array}{c}-0.356 \\
(-0.426)\end{array}$ \\
\hline$X_{t} / X_{t-1}$ & $\begin{array}{c}-0.134 \\
(-0.474)\end{array}$ & $\begin{array}{c}-0.696 \\
(-1.120)\end{array}$ & $O I_{t} / O I_{t-1}$ & $\begin{array}{l}-0.209 \\
(-0.741)\end{array}$ & $\begin{array}{c}-0.259 \\
(-0.762)\end{array}$ \\
\hline$X_{t} / X_{t-1} * D_{1973}$ & & $\begin{array}{c}0.695 \\
(0.986)\end{array}$ & $O I_{t} / O I_{t-1} * D_{1973}$ & & $\begin{array}{c}0.154 \\
(0.234)\end{array}$ \\
\hline$C F O_{t} / C F O_{t-1}$ & $\begin{array}{l}-0.593 \\
(-3.892)\end{array}$ & $\begin{array}{c}-0.619 \\
(-3.624)\end{array}$ & $C F O_{t} / C F O_{t-1}$ & $\begin{array}{c}-0.579 \\
(-3.770)\end{array}$ & $\begin{array}{c}-0.609 \\
(-3.489)\end{array}$ \\
\hline$C F O_{t} / C F O_{t-1} * D_{1973}$ & & $\begin{array}{c}0.138 \\
(0.303)\end{array}$ & $C F O_{t} / C F O_{t-1} * D_{1973}$ & & $\begin{array}{c}0.138 \\
(0.304)\end{array}$ \\
\hline$R^{2}$ & 0.225 & 0.195 & $R^{2}$ & 0.231 & 0.183 \\
\hline \multicolumn{6}{|c|}{ Panel B Predicting the aggregate future cash flow } \\
\hline & \multicolumn{2}{|c|}{$C F O_{t+1} / T A_{t}$} & & \multicolumn{2}{|c|}{$C F O_{t+1} / T A_{t}$} \\
\hline Intercept & $\begin{array}{c}0.009 \\
(1.513)\end{array}$ & $\begin{array}{c}0.008 \\
(0.597)\end{array}$ & Intercept & $\begin{array}{c}0.003 \\
(0.283)\end{array}$ & $\begin{array}{c}0.022 \\
(1.038)\end{array}$ \\
\hline$D_{1973}$ & & $\begin{array}{c}-0.009 \\
(-0.552)\end{array}$ & $D_{1973}$ & & $\begin{array}{c}-0.031 \\
(-1.155)\end{array}$ \\
\hline$X_{t} / T A_{t}$ & $\begin{array}{c}0.683 \\
(2.361)\end{array}$ & $\begin{array}{c}1.087 \\
(2.818)\end{array}$ & $O I_{t} / T A_{t}$ & $\begin{array}{c}0.101 \\
(0.442)\end{array}$ & $\begin{array}{c}-0.111 \\
(-0.373)\end{array}$ \\
\hline$X_{t} / T A_{t} * D_{1973}$ & & $\begin{array}{c}-0.614 \\
(-0.732)\end{array}$ & $O I_{t} / T A_{t} * D_{1973}$ & & $\begin{array}{c}0.527 \\
(0.830)\end{array}$ \\
\hline$C F O_{t} / T A_{t}$ & $\begin{array}{c}0.266 \\
(0.890)\end{array}$ & $\begin{array}{c}-0.116 \\
(-0.310)\end{array}$ & $C F O_{t} / T A_{t}$ & $\begin{array}{c}0.830 \\
(3.756)\end{array}$ & $\begin{array}{c}0.791 \\
(2.974)\end{array}$ \\
\hline$C F O_{t} / T A_{t} * D_{1973}$ & & $\begin{array}{c}0.874 \\
(1.311) \\
\end{array}$ & $C F O_{t} / T A_{t} * D_{1973}$ & & $\begin{array}{c}-0.187 \\
(-0.255) \\
\end{array}$ \\
\hline$R^{2}$ & 0.539 & 0.545 & $R^{2}$ & 0.485 & 0.466 \\
\hline
\end{tabular}


Panel C The accrual quality (Dechow and Dichev, 2002) pre and post FASB

$T C A_{t}$ is the aggregate total accrual in year $\mathrm{t}$, calculated as $\Delta$ Current assets $+\Delta$ Debt in current liabilities- $\Delta$ Current liabilities- $\Delta$ Cash. $S t d(v)$ is the standard deviation of estimated residuals in the pre-FASB and post-FASB regressions respectively.

\begin{tabular}{lcc}
\hline & \multicolumn{3}{c}{$T C A_{t} / T A_{t}$} \\
Intercept & Pre-FASB & Post-FASB \\
& -0.007 & -0.005 \\
$C F O_{t-1} / T A_{t}$ & $(-0.705)$ & $(-2.672)$ \\
& 0.394 & 0.375 \\
$C F O_{t} / T A_{t}$ & $(1.934)$ & $(2.594)$ \\
& -0.193 & -0.238 \\
$C F O_{t+1} / T A_{t}$ & $(-1.165)$ & $(-1.941)$ \\
$R^{2}$ & 0.044 & 0.065 \\
Std (v) & $(0.368)$ & $(0.587)$ \\
& 0.173 & 0.379 \\
\hline
\end{tabular}


Table 10

Summary Statistics for firm-level regression of predicting future cash flow

This table presents the summary statistics for the parameter estimation results of the time series regression of predicting future cash flow at the individual firm level. The time series regression is conducted for each firm with more than 20 observations in either pre-FASB period or postFASB period. Panel A presents the regression result of predicting the level of future cash flow. Panel B presents the accrual quality measure as in Dechow and Dichev (2002) at the firm level. $C F O_{i, t}$ is the operating cash flow in period $t$ for firm $i$, calculated as $X_{i, t}+$ Dep $_{i, t}$ (Depreciation)+ $\Delta D T_{i, t}$ (change in deferred tax)- $\Delta W C_{i, t}$ (change in working capital: $\Delta$ Current assets $+\Delta$ Debt in current liabilities- $\Delta$ Current liabilities- $\Delta$ Cash). $X_{i, t}$ is the net income before extraordinary items (Compustat \#18) for firm $i$ in year t. $O I_{i, t}$ is the operating income after depreciation (Compustat \#178) for firm $i$ in year t. All variables in regression are deflated by the beginning-of-period market value of each firm $\left(P_{i, t-1}\right) . T C A_{i, t}$ is firm $i$ 's total accrual in year $t$, calculated as $\Delta$ Current assets $+\Delta$ Debt in current liabilities- $\Delta$ Current liabilities- $\Delta$ Cash. The $t$-statistics reported in parenthesis in the mean column is the result from two sample t-test of coefficients of the pre- and post-FASB samples.

Panel A Earnings $X_{i, t}$ as independent variable

\begin{tabular}{|c|c|c|c|c|c|c|c|}
\hline & \multicolumn{7}{|c|}{ Pre-FASB period, 198 firms in the sample } \\
\hline & Mean & Std & Median & Min & Q1 & Q3 & Max \\
\hline Intercept & 0.081 & 0.057 & 0.072 & -0.070 & 0.041 & 0.108 & 0.307 \\
\hline$X_{i, t} / T A_{i, t}$ & 0.091 & 0.871 & 0.207 & -3.526 & -0.310 & 0.666 & 1.765 \\
\hline \multirow[t]{3}{*}{$C F O_{i, t} / T A_{i, t}$} & 0.033 & 0.342 & 0.021 & -1.180 & -0.188 & 0.218 & 1.168 \\
\hline & \multicolumn{7}{|c|}{ Post-FASB period, 997 firms in the sample } \\
\hline & Mean & Std & Median & Min & Q1 & Q3 & Max \\
\hline Intercept & 0.067 & 0.065 & 0.067 & -0.447 & 0.038 & 0.099 & 0.564 \\
\hline$X_{i, t} / T A_{i, t}$ & 0.396 & 0.995 & 0.372 & -4.132 & -0.019 & 0.759 & 18.448 \\
\hline$C F O_{i, t} / T A_{i, t}$ & -0.045 & 0.604 & -0.041 & -12.606 & -0.278 & 0.181 & 4.964 \\
\hline
\end{tabular}

Panel B Operating income $O I_{i, t}$ as independent variable

Pre-FASB period, 198 firms in the sample

\begin{tabular}{|c|c|c|c|c|c|c|c|}
\hline & Mean & Std & Median & Min & Q1 & Q3 & Max \\
\hline Intercept & 0.079 & 0.060 & 0.073 & -0.119 & 0.044 & 0.107 & 0.353 \\
\hline$O I_{i, t} / T A_{i, t}$ & 0.072 & 0.443 & 0.106 & -2.271 & -0.152 & 0.313 & 1.358 \\
\hline$C F O_{i, t} / T A_{i, t}$ & 0.038 & 0.341 & 0.027 & -1.055 & -0.199 & 0.245 & 1.128 \\
\hline & \multicolumn{7}{|c|}{ Post-1973 period, 997 firms in the sample } \\
\hline & Mean & Std & Median & Min & Q1 & Q3 & Max \\
\hline Intercept & 0.049 & 0.073 & 0.053 & -0.678 & 0.015 & 0.086 & 0.348 \\
\hline$O I_{i, t} / T A_{i, t}$ & 0.427 & 0.748 & 0.388 & -3.512 & 0.101 & 0.680 & 11.698 \\
\hline$C F O_{i, t} / T A_{i, t}$ & -0.052 & 0.391 & -0.068 & -4.518 & -0.266 & 0.148 & 1.960 \\
\hline
\end{tabular}


Panel B Firm level accrual quality measure (Dechow and Dichev, 2002)

$S t d(v)$ is the standard deviation of estimated residuals in the firm level regression of the following model:

$$
T C A_{t+1} / T A_{t}=\zeta_{0}+\zeta_{1} C F O_{t-1} / T A_{t}+\zeta_{2} C F O_{t} / T A_{t}+\zeta_{3} C F O_{t+1} / T A_{t}+\varepsilon_{t}
$$

\begin{tabular}{|c|c|c|c|c|c|c|c|}
\hline & \multicolumn{7}{|c|}{ Pre-FASB period, 256 firms in the sample } \\
\hline & Mean & Std & Median & Min & Q1 & Q3 & Max \\
\hline Intercept & 0.079 & 0.041 & 0.078 & -0.056 & 0.055 & 0.106 & 0.183 \\
\hline$C F O_{i, t-1} / T A_{i, t}$ & 0.099 & 0.145 & 0.038 & -0.233 & 0.000 & 0.186 & 0.685 \\
\hline$C F O_{i, t} / T A_{i, t}$ & -0.847 & 0.276 & -0.877 & -1.601 & -1.018 & -0.660 & -0.079 \\
\hline$C F O_{i, t+1} / T A_{i, t}$ & 0.068 & 0.145 & 0.062 & -0.358 & -0.037 & 0.169 & 0.514 \\
\hline \multirow[t]{3}{*}{$\operatorname{Std}(v)$} & 0.024 & 0.022 & 0.012 & 0.006 & 0.015 & 0.029 & 0.087 \\
\hline & \multicolumn{7}{|c|}{ Post-FASB period, 1008 firms in the sample } \\
\hline & Mean & Std & Median & Min & Q1 & Q3 & $\operatorname{Max}$ \\
\hline Intercept & 0.042 & 0.046 & 0.032 & -0.144 & 0.010 & 0.069 & 0.222 \\
\hline$C F O_{i, t-1} / T A_{i, t}$ & 0.084 & 0.172 & 0.060 & -0.663 & -0.009 & 0.189 & 0.842 \\
\hline$C F O_{i, t} / T A_{i, t}$ & -0.551 & 0.341 & -0.527 & -2.052 & -0.794 & -0.305 & 0.366 \\
\hline$C F O_{i, t+1} / T A_{i, t}$ & 0.094 & 0.175 & 0.090 & -0.678 & -0.011 & 0.198 & 1.348 \\
\hline $\operatorname{Std}(v)$ & 0.045 & 0.036 & 0.032 & 0.002 & 0.024 & 0.058 & 0.199 \\
\hline
\end{tabular}

